\title{
The Applicability of Section 337 to Sales to Third Parties in a "C" Reorganization: The $F E C$ Liquidating and General Housewares Decisions
}

The Internal Revenue Code provides as a general rule that gain or loss realized on the sale or exchange of property must be recognized "[e]xcept as otherwise provided" by the Code. ${ }^{1}$ One group of statutory exceptions to this rule involves corporate liquidations, ${ }^{2}$ and a second group pertains to corporate reorganizations. ${ }^{3}$ This Comment examines the concurrent application of these two groups of exceptions when a corporation transfers substantially all of its assets in a "C" reorganization, sells other assets to third parties, and then liquidates pursuant to the reorganization. The issue to be discussed is whether the corporation may properly claim nonrecognition of gain or loss on the sales to third parties under section 337, a liquidation provision. ${ }^{4}$

A "C" reorganization 5 involves the acquisition by one corporation (the "acquiring corporation") of substantially all of the properties of another corporation (the "transferor corporation") 6 in exchange primarily for voting stock of the acquiring corporation or its parent. ${ }^{7}$ After

I. I.R.C. $\$ 1001$ (c).

2. Id. $\$ \S 331-346$.

3. Id. $\S \S 354-368$.

4. Whether $\$ 337$ applies to the transfer of assets to the acquiring corporation if the transaction fails to qualify as a reorganization is a separate issue not discussed lierein.

5. "Reorganizations" entitled to special nonrecognition treatment are linited to the six specific types of transactions defined in subparagraphs (A) through $(F)$ of $\S 368(a)(1)$. These statutory reorganizations are custonarily referred to by subparagraph letter. Tlius a "C" reorganization is one defined in $\S 368(\mathrm{a})(1)(\mathrm{C})$.

6. Relevant factors in determining whether "substantially all of the properties" of the transferor corporation are acquired for purposes of $\S 368(a)(1)(C)$ include the nature and anount of the properties retained by the transferor corporation and the purpose of the retention. Rev. Rul. 57518, 1957-2 C.B. 253, 254. For ruling purposes, the Internal Revenue Service requires the transfer of at least $90 \%$ of the fair market value of the net assets and $70 \%$ of the fair market value of the gross assets held by the transferor corporation immediately prior to the transfer. Rev. Proc. 7737, 1977-2 C.B. 568, 569. This ruling position does not define the lower limits of the "substantially all" requirements as a matter of law, lowever. Id.

For a general discussion of the "substantially all" requirement, see B. BITTKER \& J. EUSTICE, Federal Income Taxation of Corporations and Shareholders $14-41$ to $14-45$ (3d ed. 1971) [hereinafter cited as BITTKER \& EUSTICE].

7. Section $368(a)(1)(C)$ states that the acquisition must be in excliange solely for all or a part of the voting stock of the acquiring corporation or of its parent, but several statutory provi- 
this exchange the transferor corporation is a holding company. Typically it liquidates as part of the plan of reorganization ${ }^{8}$ and distributes all of its assets (solely or primarily stock in the acquiring corporation or its parent) to its shareholders in exchange for all of their stock in the transferor corporation. In general, neither the acquiring corporation ${ }^{9}$ nor the transferor corporation ${ }^{10}$ recognizes gain or loss on the reorgani-

sions relax this requirement to a limited extent. For example, that the acquiring corporation assumes a liability of the transferor corporation or takes property subject to a liability is disregarded. I.R.C. \& 368(a)(1)(C). (In a triangular " $C$ " reorganization, the assumption by the acquiring corporation's parent of a liability of the transferor corporation is generally not disregarded, however. See note 22 infra). Also, consideration other than voting stock may be given if at least $80 \%$ of the gross fair market value of all the property of the transferor corporation is acquired for voting stock. I.R.C. $\& 368(\mathrm{a})(2)(\mathrm{B})$. For the limited purpose of determining whether $80 \%$ of all property is acquired for voting stock, liabilities assumed by the acquiring corporation or to which the acquired property is subject are treated as money paid for the property. $I d$. Thus if the liabilities assumed exceed $20 \%$ of the fair market value of all the properties of the transferor corporation, as is generally the case, no consideration other than voting stock may be given by the acquiring corporation. See generally BITTKER \& EusTiCE, supra note 6, at $14-45$ to $14-49$.

8. The transferor corporation is not required to liquidate in a " $C$ " reorganization, however. See Helvering v. Minnesota Tea Co., 296 U.S. 378 (1935); John A. Nelson Co. v. Helvering, 296 U.S. 374 (1935); World Serv. Life Ins. Co. v. United States, 471 F.2d 247 (8th Cir. 1973); Rev. Rul. 73-552, 1973-2 C.B. 116; Rev. Rul. 68-358, 1968-2 C.B. 156. For a discussion of the use of a "C" reorganization in which the transferor corporation does not liquidate, see Bloom, How to use a non-liquidating $C$ reorg and avoid running afoul of the overlaps, $42 \mathrm{~J}$. TAX. 358 (1975).

9. The acquiring corporation is accorded nonrecognition treatment under $\S 1032$ on the exchange of its own stock for the properties of the transferor corporation. There is no statutory provision that accords nonrecognition treatment to an acquiring corporation which uses the stock of its parent as consideration, but the Internal Revenue Service has ruled (without discussion) that the subsidiary does not recognize gain or loss in this situation. See Rev. Rul. 57-278, 1957-1 C.B. $124,126$.

The basis of property received by the acquiring corporation in a reorganization is ordimarily equal to the basis of the property in the hands of the transferor corporation, imcreased by any gain recognized to the transferor corporation on the transfer. I.R.C. \& 362(b).

10. Section 361 (a) provides that the transferor corporation does not recognize gain or loss on the exchange of its property solely for stock in the acquiring corporation or its parent. If the transferor corporation receives any boot, it must recognize its gam on the exchange to the extent of the fair market value of the boot received unless it distributes the boot to its shareholders as part of the plan of reorganization. I.R.C. \& 361(b)(1). Application of the boot to pay debts of the corporation does not qualify as a distribution under $\$ 361(b)(1)$, nor does a transfer of cash boot to the shareholders together with corporate liabilities. See Minnesota Tea Co. v. Helvering, 302 U.S. 609 (1938).

The basis to the transferor corporation of stock received in a " $\mathrm{C}$ " reorganization is the same as the transferor's basis in the property it transfers, mcreased by any gain (or decreased by any loss) recognized to it on the exchange, and decreased by the fair market value of any boot rcceivcd and by the amount of any liabilities assumed by the acquiring corporation on the exchange. I.R.C. $\S 358(\mathrm{a})(1)$, (d). The basis of any other property received is its fair market value. Id. $\S$ 358(a)(2). If the transferor corporation is liquidated pursuant to the reorganization, these basis rules are of importance only if it disposes of part of the property received (for example, to pay the expenses of the reorganization, see note 13 infra).

It is also well-established that the transferor corporation does not recognize gam or loss if it distributes its assets to its shareholders pursuant to the plan of reorganization. The statutory authority for nonrecognition on this excliange is generally assumed to be $\S 336$. See note 90 infra and accompanying text. 
zation exchanges. The shareholders of the transferor corporation generally do not recognize gain or loss if they receive only stock in the acquiring corporation or its parent in the hquidating distribution. ${ }^{11}$ If they also receive cash or other property, however, they inust immediately recognize any gain to the extent of the sum of the money and the fair market value of the other property received. ${ }^{12}$

The acquiring corporation is not required to assume the liabilities of the transferor corporation in a "C" reorganization. ${ }^{13}$ To satisfy habilities that it retains ${ }^{14}$ or for other reasons, ${ }^{15}$ the transferor corporation might sell part of its assets to third parties before it hiquidates. No reorganization provision permits nonrecognition of gain or loss by the transferor corporation on sales to third parties made in the course of a reorganization. Nonrecognition treatment would be appropriate, however, if section 337 applies.

11. I.R.C. $\S 354(\mathrm{a})(1)$. This general nonrecognition rule is not applicable, lowever, if (1) the principal amount of securities received exceeds the principal amount of securities surrendered, or (2) securities are received and no securities are surrendered. Id. §354(a)(2). See generally BirTKER \& EUSTICE, supra note 6, at 14-87 to 14-88.

12. I.R.C. $\$ 356$ (a)(1). Section 356 applies only to shareholders who receive boot in addition to stock in the acquiring corporation or its parent. Distributions of boot alone (for example to dissenting shareholders who are paid in cash) are treated as redemptions under $\S 302$. Rev. Rul. 74-515, 1974-2 C.B. 118; Rev. Rul. 73-102, 1973-1 C.B. 186; see Treas. Reg. § 1.3541(d) (1955) (example 3).

The basis to a shareholder of the stock received in a $\$ 354$ or $\$ 356$ exchange is the same as that of the stock in the transferor corporation surrendered, decreased by the fair market value of any boot received and increased by the amount of any gain (including the amount of any dividend income) recognized to the shareholder on the exchange. I.R.C. \& 358(a)(1). Thus assuming that the stock received does not change in value, any gain or loss deferred on the liquidating distribution will be recognized when the stock is ultimately disposed of in a taxable transaction. (This deferral theory inay be breached in practice, however, if the shareholder holds the stock received in the exchange until his death. See id. $\S \S 1014,1023(\mathrm{~h})$.)

13. A transferor corporation might choose to retain some of its liabilities in a " $\mathrm{C}$ " reorganization because habilities whose nature and amount are determined and fixed in the reorganization may constitute boot under the principle of Helvering v. Southwest Consol. Corp., 315 U.S. 194 (1942). See, e.g., Rev. Rul. 73-102, 1973-1 C.B. 186 (amounts paid by the acquiring corporation to satisfy claims of the transferor corporation's dissenting shareholders held to be boot imder the Southwest Consolidated principle). The assumption of such liabilities by the acquiring corporation would invalidate the "C" reorganization unless the "boot relaxation" rule of $\S 368(a)(2)(B)$, see note 7 supra, applied.

14. To discharge its liabilities, the transferor corporation might sell assets prior to the reorganization, or it might retain part of its assets for subsequent sale. Both these approaches may be circumscribed, however, by the requirement that substantially all of the transferor corporation's assets be trausferred to the acquiring corporation in the "C" reorganization. See note 6 supra and accompanying text. The transferor corporation might alternatively discharge its retamed liabilities by selling part of the stock or other assets which it received as consideration from the acquiring corporation. See, e.g., Sinrich \& Baller, Payment in Buyer's Stock-Tax-Free Acquisitions of Businesses-The Tax-Free Reorganization, in I Business AcQuisitions: PlanNing AND PrACTICE 463, 481 (Practising Law Institute 1971). This latter approach was taken by the taxpayers in the two cases that are the focus of this Cominent.

15. For example, the transferor corporation might have retained a limited anount of assets that the acquiring corporation did not wish to acquire, see note 6 supra and accompanying text, and it might not be practical or desirable to distribute these assets in kind to the shareholders. 
Section 337(a) provides that a corporation which adopts a plan of coinplete hquidation and distributes all of its assets in coinplete liquidation within the following twelve inonths does not recognize gain or loss from the sale or exchange of its properties during this twelvemonth period. Section 337 is technically not elective because a corporation cannot choose to avoid its apphication if the statutory requiresnents have been met. ${ }^{16}$ The provision is elective, however, in the sense that a corporation inay plan and execute the hquidation so as to fall within or without the rules of the section. ${ }^{17}$

It is possible for a transferor corporation that inakes sales to third parties and then liquidates pursuant to both a " $\mathrm{C}$ " reorganization and a plan of complete liquidation to ineet the statutory requirements of section 337. In FEC Liquidating Corp. v. United States, ${ }^{18}$ however, the Court of Claims held that section 337 does not apply in this situation because a "reorganization" and a "coinplete liquidation" are by definition mutually exclusive. A United States District Court rejected this reasoning in General Housewares Corp. v. United States ${ }^{19}$ and allowed nonrecognition of gain under section 337 on facts similar to those in FEC. ${ }^{20}$

16. See, e.g., Anchorage Nursing Hoine, Inc., 33 T.C.M. (CCH) 1372 (1974); Bird Management, Inc., 48 T.C. 586 (1967). 113.

17. See, e.g., Vern Realty, Inc., 58 T.C. 1005, 1009 (1972), affd mem., 73-1 U.S. Tax Cas. 81,

1t is soinetimes possible for a corporation to straddle $\S 337$ by selling its depreciated property before the shareholders adopt the liquidation plan and selling its appreciated property thereafter. See generally BITTKER \& EUSTICE, supra note 6, at 11-59 to 11-61; Kovey, Rigged Answers to Troublesome Liquidation Plan Questions, 54 TAXEs 260, 263-65 (1976). A corporation that has adopted a plan of complete liquidation can avoid $\S 337$ altogether by dehberately delaying the distribution of part of its assets beyond the twelve-1nonth period. Rev. Rul. 77-150, 1977-1 C.B. 88. See also Bird Management, Inc., 48 T.C. 586, 594 (1967).

18. 548 F.2d 924 (Ct. Cl. 1977) (Nichols, J.).

19. Nos. CA 75-G2028S and CA 75-M0782S (N.D. Ala. Aug. 31, 1977) (Guin, J.) (cases consolidated for the reason discussed at note 39 infra), appeal docketed, No. 78-1241 (5th Cir. Feb. I, 1978).

20. FEC and General Housewares are apparently the only cases in which this issue has been directly addressed. A few cases have considered whether $§ 337$ applies to sales to third parties by a transferor corporation that liquidates pursuant to a " $D$ " reorganization (transfer of assets to controlled corporations, see I.R.C. \& 368(a)(I)(D)). Those cases were concerned primarily with tax avoidance in the liquidation-reincorporation context, however, and they do not establish that \& 337 can never apply to sales to third parties in the context of a reorganization. See notes 85-86 infra and accompanying text.

In Rev. Rul. 70-271, 1970-1 C.B. 166 (situation 1), the Internal Revenue Service impliedly demed the apphicability of $\S 337$ in the context of a " $C$ " reorganization. That ruling involved a transaction in which a transferor corporation discharged a retained liabihity by transferring part of the stock it had received in the reorganization to a creditor. Noting that the transfer of stock in satisfaction of an outstanding obhigation is equivalent to a sale pursuant to $\S 1001$, the Service ruled that the gain realized by the transferor corporation on the transfer of the stoek must be recognized under $\S 1002$ (now $\S 1001(\mathrm{c})$ ). The ruling did not mention $\S 337$ or why it was not applicable to the transfer in question. 
This Comment exammes whether section 337 should apply to sales to third parties by a transferor corporation in a " $\mathrm{C}$ " reorganization. Part I reviews the FEC and General Housewares decisions and discusses the courts' reasoning. Part II demonstrates that the mutual exclusivity theory under which the Court of Claims denied section 337 treatment in $F E C$ is unsupportable. Part III analyzes and refutes the government's argument in these two cases that section 337 cannot apply in a reorganization because recognition of the shareholders' gaim or loss on the liquidating distribution is governed by the reorganization rather than the hquidation provisions. Finally, Part IV discusses the reasons for the enactment of section 337 and shows that the application of section 337 in the present context is consistent with the legislative purpose of that provision.

\section{I}

THE FEC LIQUIDATING AND GENERAL HOUSEWARES

\section{DECISIONS}

\section{A. FEC Liquidating Corp. v. United States}

\section{The Facts}

Fanon Electronic Industries, Inc. ${ }^{21}$ and Whittaker Corporation entered into an acquisition agreement and plan of reorganization under which Fanon agreed to transfer substantially all of its assets to a Whittaker subsidiary in exchange for Whittaker common stock and Whittaker's assumption of certain of Fanon's liabilities. ${ }^{22}$ Fanon retained all of its liabilities not expressly assumed by Whittaker. The transaction qualified as a tax-free "C" reorganization. Since one of the assets being acquired was the right to use Fanon's name, Fanon agreed to change its name to FEC Liquidating Corp. ${ }^{23}$

FEC also adopted a plan of complete liquidation. Both the liquidation plan and the reorganization plan provided that FEC would sell enough of the Whittaker stock it received to discharge the habilities not

21. The opinion erroneously referred to this corporation as Fanon Electronics Industries, Inc. 548 F.2d at 925.

22. Acquisition Agreement and Plan of Reorganization 1 (recitals) \& para. 5.2.1 (Sept. 15, 1967) (attached to Stipulatiou of Facts as Exhibit 1A).

If the acquiring corporation's parent assumes liabilities of the transferor corporation in a triangular "C" reorganizatiou, as was doue in $F E C$, the solely for voting stock requirement of $\S$ $368(a)(1)(C)$ will not be met unless the boot relaxation rule of $\S 368(a)(2)(B)$, see note 7 supra, is satisficd. See Rev. Rul. 70-107, 1970-1 C.B. 78; Profit Mate, Inc., 36 T.C.M. (CCH) 568, 573 n.8 (1977). Also, the pareut's assumption of the liabilities triggers recognition of the transferor eorporation's gain on the exchange, if any, under $\S 361(\mathrm{~b})(1)$, see note 10 supra. See BirTKER \& EUSTICE, supra note 6 , at 14-82. For thcse reasons, the pareut normally does not assume the transferor corporation's liabilities.

23. Acquisition Agreement and Plan of Reorganizatiou, supra note 22, at para. 3.4. Fanon is hereinafter referred to as FEC. 
assumed by Whittaker. FEC would then liquidate and distribute the remaimder of the Whittaker shares to its shareholders in cancellation of all of their FEC stock. The liquidation plan provided further that the liquidation would be completed within twelve months after the adoption of that plan. ${ }^{24}$

After the stock for assets exchange was executed, FEC sold some of its newly acquired Whittaker stock to third parties for cash and used the proceeds to pay its retamed liabilities. ${ }^{25}$ Within twelve months of the date on which the liquidation plan was adopted, FEC distributed the remainder of the Whittaker stock in complete liquidation. The distributed stock represented less than one percent of Whittaker's total outstanding stock. ${ }^{26}$ The FEC shareliolders treated the liquidating distribution as having been made in exchange for their stock in the transferor corporation pursuant to the reorganization, and accordingly they did not recognize gain or loss on the distribution. ${ }^{27}$

On its tax returns for the periods encompassing the sales to third parties, FEC recognized gain on the sales and paid the tax attributable to the gain. ${ }^{28}$ It subsequently filed claims for refund on the ground that the gam sliould not have been recognized because section 337 applied. ${ }^{29}$ The Commissioner disallowed the claims, and FEC brought

24. 548 F.2d at 925 .

25. Plaintiffs' Brief in Support of Motion for Summary Judgenent at 1.

26. As of August 31, 1967 (three inonths before the plan of coinplete liquidation was adopted by the FEC shareholders), Whittaker had 4,082,302 shares of common stock and 413,674 shares of preferred stock outstanding. Acquisition Agreenent and Plan of Reorganization, supra note 22, at para. 4.3.1. Whittaker transferred 48,480 shares of common stock to FEC pursuant to the "C" reorganization. Plaintiffs' Brief in Support of Motion for Suinmary Judgment at 1. FEC sold a total of 5,776 shares to pay its liabilities. See id. Thus the remaining 42,704 shares that FEC distributed in complete hiquidation represented about one percent of the outstanding common stock of Whittaker and less than one percent of the total value of the outstanding Whittaker common and preferred stock.

27. See I.R.C. \& 354 (discussed at note 11 supra and accompanying text).

28. Cross-Motion of the United States for Partial Summary Judgment and Brief in Support Thereof and in Opposition to Plaintiffs' Motion for Summary Judgment at 6 [hereinafter cited as Brief for the Defendant, $F E C$ ].

29. In rebutting the government's argument in $F E C$ that $\$ 337$ should not apply at the corporate level because $\$ 331$ did not apply at the shareholder level, see notes 98-99 infra and accompanying text, FEC noted that virtually all of its shareholders had sold the Whittaker stock they received. Thus gain had actually been recognized at the shareholder level notwithstanding the applicability of § 354. Plaintiff's Reply Brief to Defendant's Brief in Support of Cross-Motion for Summary Judgment and in Reply to Defendant's Brief in Opposition to Plaimtiff's Motion for Summary Judgment at 17. While perhaps bolstering the position that $\S 337$ should apply, such an argument could lave jeopardized the reorganization because of the contimuity-of-interest requirement discussed at note 53 infra and accompanying text.

FEC filed its refund claims only a few days before the statute of himitations on its fmal returns was due to run. See Plaintiffs' Petition at paras. 18, 21, 47, 50; I.R.C. $\S 6501$. Since the statute of limitations on a federal income tax return begins to run from the date of the filing of the original return even if an ainended return is subsequently filed, see Alfonzo L. Dowell, 68 T.C. 646, 649-50 (1977), appeal docketed, No. 78-1341 (10th Cir. May 5, 1978), FEC may have timed its refund claims so that the statute of limitations would have run on the reorganization before it 
suit in the Court of Claims to recover the taxes paid.

\section{The Decision}

The Court of Claims structured its opinion by summarizing its understanding of the government's and FEC's arguinents and then concluding that the former were persuasive.

The government conceded that the transaction in question inet the hiteral requirements of section 337 but argued that hiteral comphance with statutory criteria does not entitle a taxpayer to the desired treatment if that result contravenes an underlying tax policy. According to the government, the cornerstone of a qualifying corporate reorganization is that the shareholders retain a proprietary imterest in the business which continues in modified corporate form. A corporate liquidation, on the other hand, occurs when the shareholders surrender their interests in the busmess and disassociate themselves from it. Since contimuity of interest is logically mcompatible with disassociation from the business, the government argued that a given transaction could be either a reorganization or a hquidation but could never be both. ${ }^{30}$

As support for its theory that liquidations and reorganizations are mutually exclusive, the government cited a comment im the treatise on corporate taxation by Professors Bittker and Eustice. The authors state that, in a transaction deemed to be a reorganization rather than a liquidation, the reorganization sections preempt section 337 and section 337 does not apply even to sales to third parties. ${ }^{31}$. They draw this conclusion from a series of Tax Court cases that apphed the reorganization provisions and denied the applicability of the liquidation provisions to transactions in which taxpayers liquidated their corporations and reincorporated the operating assets in separate corporations that they controlled. ${ }^{32}$ The government argued that these cases supported its theory that corporate hquidations and corporate reorganizations cannot coex-

brought the shareholders' sales of their stock to the attention of the Internal Revenue Service by filing the refund claims based on $\$ 337$.

30. 548 F.2d at 926.

31. Id. The passage referred to states: A point to be noted in this context, however, is that $\$ 337$ is preempted by the reorganization provisions if the transaction is held to constitute a reorganization rather than a liquidation. Moreover, it has been held that $\$ 337$ is ousted of jurisdiction even over sales to outsiders in a liquidation occurring in the course of a reorganization.

BITTKER \& EusTICE, supra note 6, at 11-78 (footnote omitted). The context referred to in the first line is the liquidation-reincorporation situation that is described at note 55 infra and accounpanying text.

32. BITTKER \& EUSTICE, supra note 6, at 11-78 n.143 (citing, among other authorities, Werner Abegg, 50 T.C. 145 (1968), affd, 429 F.2d 1209 (2d Cir. 1970), cert. denied, 400 U.S. 1008 (1971), and Ralph C. Wilson, Sr., 46 T.C. 334 (1966)). The government also cited Davant v. Commissioner, 366 F.2d 874 (5th Cir. 1966), cert. denied, 386 U.S. 1022 (1967), and James Armour, Inc., 43 T.C. 295 (1964). Sce 548 F.2d at 926. 
ist for tax purposes because of the contradictory nature of these transactions.

FEC denied that the concurrent application of the liquidation and reorganization provisions necessarily offends any tax policy. It supported its position with a different passage from the Bittker and Eustice treatise, which states in part:

Use of $\S 337$ to obtain non-recognition [sic] for gains realized on dealings with outsiders in the context of a reorganization cum liquidation of the transferor does not seem to be prohibited by any express provisions of the statute or by any compelling reasons of policy. ${ }^{33}$

FEC noted that each of the liquidation-remcorporation cases relied on by the government imvolved a transfer of assets between two corporations both of which were controlled by the same shareholders. In those cases it was appropriate to disregard the purported liquidation and to recast the whole transaction as a " $D$ " or " $F$ " reorganization, ${ }^{34}$ as the courts had done, because the shareholders who possessed control over the assets at the outset maintained control at the end. In contrast, im $F E C$ the shareholders of the liquidated corporation relinquished control of the corporate assets when the assets were transferred to the Whittaker subsidiary. Since the liquidation-reincorporation cases were distmguishable, FEC contended that it should not be denied section 337 treatment under the precedent of those decisions. ${ }^{35}$

The court agreed with FEC that the liquidation-reincorporation cases cited by the government were distinguishable, and it therefore declined to base its decision solely on their authority. But the court found the cases to be instructive because in each the transaction in

33. 548 F.2d at 926-27 (quoting BitTKer \& Eustice, supra note 6, at 14-81). The full passage from the Bittker and Eustice treatise states:

If the transferor corporation is required to recognize gain on the disposition of part of its assets, either because boot received from the acquiring corporation is not fully distributed to shareholders, or because part of its assets are sold to persons other than the acquiring corporation, is it nevertheless possible to claim the nonrecognition benefits of $\$ 337$ with respect to this gain? Use of $\$ 337$ to obtain nonrecognition for gains realized on dealings with outsiders in the context of a reorganization cuin hiquidation of the transferor does not seem to be prohibited by any express provisions of the statute or by any coinpelling reasons of policy. Priority of the reorganization rules is probably justified where gain would be recognized under $\$ 361$, absent applicability of $\$ 337$, since $\$ 337$ ought not to be allowed to function as a backstop to $\$ 361$ where the two conflict; but nonrecognition of gain under $\$ 337$ from sales to outsiders (even though effected as part of the overall plan of reorganization) does not seem to be incompatible with the provisions of $\$ 361$, whose focus is on dealings between the transferor corporation and the acquiring corporation. Even so, however, the Service, in Rev. Rul. 70-271, and the courts have so far denied use of $\$ 337$ to a corporation that is also subject to the jurisdiction of $\$ 361$.

BITTKER \& EustiCE, supra note 6, at 14-81 (footnotes, citations, and cross-refcrences omitted).

34. For purposes of those cases, a " $D$ " reorganization is a transfer by a corporation of substantially all of its assets to a controlled corporation, followed by a complete liquidation of the transferor corporation. I.R.C. $\S 368(\mathrm{a})(1)(\mathrm{D})$; see id. $\S 354(\mathrm{~b})(1)$. An " $\mathrm{F}$ " reorganization is "a nere change in identity, forn, or place of organization, however effected." $I d$. $\& 368(\mathrm{a})(1)(\mathrm{F})$.

35. 548 F.2d at 927. 
question was taxed either as a liquidation or as a reorganization but never as both. The court accepted the government's theory that reorganizations and hquidations are mutually exclusive because this theory explained the liquidation-reincorporation decisions as well as the results in two similar cases decided by the Court of Claims. ${ }^{36}$

\section{B. General Housewares Corp. v. United States}

\section{The Facts}

The facts of General Housewares are virtually identical to the facts of FEC. U.S. Industries, Inc. (USI) and Olivier Company, Inc. entered into an agreement which provided that Ohvier would transfer its sole asset, all of the outstanding stock of a third corporation, to USI in exchange for USI stock in a "C" reorganization. Olivier also adopted a plan of coinplete liquidation. Following the exchange between USI and Olivier, Olivier sold part of its newly acquired USI stock to unrelated third parties and used most of the proceeds to pay its creditors. It then distributed all of its assets (the remaining shares of USI stock plus $\$ 98,004)$ to its shareholders, who recognized their gain to the extent of the cash they received ${ }^{37}$ After receiving the liquidating distribution, these shareholders owned a total of $.6 \%$ of the outstanding USI stock. ${ }^{38}$

On its final tax return, Olivier disclosed its gain from the sales of the USI stock but did not include the gain in incorne because it contended that section 337 applied. The Internal Revenue Service disagreed. The former shareholders of Olivier, who were the transferees of the assets distributed in liquidation, paid the tax attributable to the gain and brought suit for a refund in the district court. ${ }^{39}$

\section{The Decision}

The district court disagreed with the Court of Claims' holding in $F E C$ that a "complete liquidation" and a "reorganization" are necessarily mutually exclusive. ${ }^{40}$ Looking to the regulations and the legislative history of the liquidation provisions, it concluded that the term "complete liquidation" should generally take on its normal inean-

36. Id. (citing Mitchell v. United States, 451 F.2d 1395 (Ct. Cl. 1971), and Simon Trust v. United States, 402 F.2d 272 (Ct. Cl. 1968)). These cases are discussed at note 79 infra.

37. See I.R.C. $\$ 356$ (discussed at note 12 supra and accompanying text).

38. General Housewares Corp. v. United States, Nos. CA 75-G2028S and CA 75-M0782S, slip op. at 2-3 (N.D. Ala. Aug. 31, 1977), appeal docketed, No. 78-1241 (5th Cir. Feb. 1, 1978).

39. General Housewares was the successor in interest to Plantation Patterns, Inc., which had owned two-thirds of the stock of Olivier, William D. Sellers owned the reinaining oue-third. Id. at 2. As transferees of Olivier, General Housewares and Mr. Sellers were liable for the deficiency

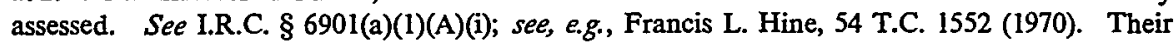
refund claims were consolidated for purposes of resolving the common issues of fact and law. Ship op. at 1.

40. Slip op. at 6 . 
ing - the distribution of substantially all of the corporate assets and the dissolution of the corporate shell. ${ }^{41}$ This definition of a liquidation is not conceptually incompatible with that of a reorganization. As support for the notion that the liquidation and the reorganization provisions can coexist in a single transaction, the court stated that a liquidation provision, section 336, provides nonrecognition treatnent to a transferor corporation when it hquidates pursuant to a reorganization. ${ }^{42}$

According to the court, there is only one type of transaction in which liquidation treatment should not apply if a complete hquidation has occurred within the "normal meaning" of that term. In a hquidation-reincorporation, where part of the assets of the hquidated corporation are reincorporated in another corporation controlled by substantially the same shareholders, hquidation treatment is inappropriate because the purported "complete liquidation" may be undertaken for tax avoidance purposes. ${ }^{43}$ In General Housewares, however, there was no possibility of abuse of the liquidation provisions because the shareholders who had owned $100 \%$ of Ohvier wound up owning less than one percent of USI. They had exchanged their control over a small holding company for the stock of a large national corporation. In the court's view, these facts clearly distinguished General Housewares froin the liquidation-remcorporation cases in which the liquidation provisions are mapplicable. ${ }^{44}$

The government inade the additional argument that nonrecognition of corporate gain under section 337 is imphicitly linked to recognition under section 331 of any gam realized by the shareholders on the hquidatimg distribution. Thus in the government's view section 337 should not apply in the context of a reorganization, simce recognition of the shareholders' gain or loss on a distribution pursuant to a reorganization is ordinarily governed by sections 354 and $356 .^{45}$ The government argued alternatively that, if section 337 applies in the context of a reorganization, the shareholders must immediately recognize the full amount of their gain or loss under section $331 .{ }^{46}$

41. Id. at 7. It is unclear why the court thought that dissolution of the corporate shell is a prerequisite for a "complete liquidation." While the regulations under $\$ 337$ do not address this question, the regulations under $\$ 332$ pertaining to the "complete hquidation" of subsidiaries state that "legal dissolution of the corporation is not required." Treas. Reg. $\$ 1.332-2$ (c) (1955). The General Housewares opinion quoted this regulation with apparent approval. Shp op. at 6 .

42. Slip op. at 24-27.

43. Id. at 7-20. These tax avoidance objectives are discussed at notes 56-59 infra and accompanying text.

44. Slip op. at 20-21.

45. See id. at 27-28. See also Brief for the Defendant at 30-32. The government also made this argument in its FEC briefs, see Brief for the Defendant, FEC, supra note 28, at 22-23, but the Court of Claims did not refer to the argument in its opinion.

46. See slip op. at 28-29. See also Brief for the Defendant at 37-44. 
The court rejected both arguments as contrary to section 337 and its legislative history. ${ }^{47}$ It also noted that section 331 is not a recognition provision but rather defmes the character (i.e., capital versus ordinary) of gain or loss recognized pursuant to section 1001(c), the general recognition provision of the Code ${ }^{48}$ The court concluded that Olivier should not recognize its gain on the sales to third parties under section 337 and that Olivier's shareholders should recognize their gain on the liquidating distribution only to the extent of the cash received under section 356.

\section{II}

\section{The Mutual Exclusivity Theory}

\section{A. The Compatability of the Requirements for Reorganizations and Liquidations}

The mutual exclusivity theory adopted by the Court of Claims in $F E C$ was based on the implicit assumption that there cannot be a complete liquidation if any of the shareholders of the transferor corporation retain an equity interest in the acquiring corporation. Since continuity of proprietary interest is one of the requirements for a reorganization, the court concluded that a simgle transaction can be either a reorganization or a liquidation but can never be both. The fallacy in this reasoning is that the continuity-of-interest requirement for a reorganization is completely different than the continuing shareholder interest that may render a liquidation "incomplete."

\section{The Continuity-of-Interest Requirement for a Reorganization}

Congress granted special tax treatment to statutory reorganizations because it realized that the tax laws should not prevent corporations from undertaking economic restructurings necessary to meet their changing business needs where the new corporate structure is substantially a continuation of the old. ${ }^{49}$ To confine the benefits of the reorganization provisions to restructurings of continuing corporate entities,

47. Slip op. at 28,30 .

48. The court's reasoning was as follows: Section 331 says nothing about the recognition of gain or loss upon the liquidation of a corporation. It merely provides that the liquidating distribution shall be treated by the shareholders as payment in exchange for their stock and thus brings a liquidating distribution within the "sale or exchange" requirement of the capital gain provisions of $\S 1222$. Recognition of the shareholders' gain or loss on the distribution is governed by $\S 1002$ (now § 1001(c)), which provides that the entire amount of gain or loss on a sale or exchange of property must be rccognized except as otherwise provided by the Code. Section 354 as modified by $\S 356$ is one of the provisions that provides otherwise. Thus where a corporation liquidates as part of a plan of reorganization, $\$ \$ 354$ and 356 control the "recognition" of any gain or loss realized on the "exchange." Ship op. at 29-30.

49. See, e.g., Treas. Reg. § 1.368-1(b) (1955); Turnier, Continuity of Interest-Its Application to Shareholders of the Acquiring Corporation, 64 CALIF. L. REV. 902, $912-16$ (1976). 
the Code and the courts have imposed a "continuity-of-interest" requirement on the transferor corporation and its shareholders. ${ }^{50}$ This requirement focuses on (1) the type of consideration given by the acquiring corporation (stock versus debt or other property); ${ }^{51}$ (2) the proportion of the shareholders of the transferor corporation who maintain a continuing equity interest in the reorganized corporation; ${ }^{52}$ and (3) the length of time those shareholders retain their equity interest in the reorganized corporation..$^{53}$ All of these elements of the continuity-ofinterest requirement were apparently satisfied in FEC and General Housewares. ${ }^{54}$

50. The continuity-of-interest doctrine as it is presently construed appears to apply only to the transferor corporation and its shareholders and not to the acquiring corporation or its shareholders. See BITTKer \& Eustice, supra note 6, at S14-3 to S14-4 (Cuin. Supp. No. 11978 by J. EUSTICE) [hereinafter cited as BITTKER \& EUSTICE Supp.]. For an argument that the requirement should not be so limited, see Turnier, supra note 49 , at 928-42.

For a general discussion of the continuity-of-interest requirement, see BITTKER \& EUSTICE, supra note 6, at 14-16 to 14-26; Bloom \& Sweet, How IRS uses continuity of interest 10 raise new problems in reorganizations, $45 \mathrm{~J}$. TAX. 130 (1976).

51. See, e.g., Helvering v. Minnesota Tea Co., 296 U.S. 378 (1935) (the transferor corporation must acquire an interest in the affairs of the acquiring corporation which represents a substantial percentage of the value of the assets transferred); Cortland Specialty Co. v. Commissioner, 60 F.2d 937 (2d Cir. 1932), cert. denied, 288 U.S. 599 (1933) (a reorganization presupposes that the transferor corporation or its shareholders have a continuity of interest in the properties transferred).

This aspect of the continuity-of-mterest requirement will necessarily be satisfied in a "C" reorgamization, smce the consideration given by the acquiring corporation must be primarily its own voting stock or that of its parent. See note 7 supra.

52. See Treas. Reg. $\S 1.368-1$ (b) (1955). The Internal Revenue Service will issue a ruling if one or more shareholders of the transferor corporation have a continuing cquity interest in the acquiring corporation or its parent that is equal in value as of the date of the reorganization to at least $50 \%$ of the value as of the same date of all the transferor corporation's outstanding stock. Rev. Proc. 77-37, 1977-2 C.B. 568, 569. This ruling position does not establish the lower limits of the continuity-of-interest requirement as a matter of law, however. Id.

53. In determining whether the value of the stock acquired by the transfcror corporation's shareholders ineets the $50 \%$ ininimum that is discussed in note 52 supra, the Intcrnal Revenue Service takes into consideration any transactions that occur prior to or subsequent to the exchange that are part of the plan of reorganization. Rev. Proc. 77-37, 1977-2 C.B. 568, 569. Thus if the shareholders of the transferor corporation promptly and as part of a preconceived plan dispose of the stock they reccive in the acquiring corporation or its parent, the continuity-of-interest doctrine may be apphed to invahidate the reorganization. Shareholders of the transferor corporation apparently may dispose of part or all of the stock they receive without invalidating the reorganization, however, if there is no intention to dispose of the stock at the time of the reorganization. See Bloom \& Sweet, supra note 50, at 133-34; BiTTKER \& EUSTice, supra note 6, at 14-22 to 1423.

54. FEC noted in one of its briefs that virtually all of its shareholders had sold the Whittaker stock which they had reccived in the hquidating distribution. See note 29 supra. In auditing FEC's final returns, however, the Internal Revenue Service apparently did not question the postacquisition continuity of shareholder interest. 


\section{The Continuing Interest that May Render a Liquidation "Incomplete"}

\section{a. The Requirement of Shareholder Disassociation}

As discussed in the preceding section, the continuity-of-interest requirement for a reorganization mandates that a substantial proportion of the transferor corporation's shareholders maintam a continumg equity interest in the acquiring corporation. The proportion of the outstanding shares of the acquiring corporation that this continuing interest represents is irrelevant. In the context of a liquidation, however, the focus of the inquiry is on the latter consideration-whether a substantial percentage of the outstanding shares of the transferee corporation are owned by the shareholders of the liquidated corporation-without regard to the proportion of the shareholders of the hquidated corporation who inaintain an interest in the transferee corporation. Such an inquiry is necessary to ensure that the hquidation provisions are not used for tax avoidance purposes.

The liquidation provisions offer a variety of tax advantages that might prompt taxpayers to undertake a so-called "hquidationreincorporation" transaction in which a corporation is liquidated and its operating assets are reincorporated in another corporation controlled by the saine shareholders. ${ }^{55}$ Such a transaction is a liquidation in form, but in substance the operation and ownership of the corporate business continue substantially as before. Typically the goal of a liquidation-reincorporation is to extract corporate earnings and profits as capital gains under section $331,{ }^{56}$ rather than as dividends, by distribut-

55. The liquidation-reincorporation sequence generally follows one of the following two patterns. In the first, the original corporation liquidates and transfers all of its assets to its shareholders who in turn transfer all or part of the operating assets to a second corporation that they control. In the second pattern, the original corporation transfers all or part of its operating assets to a second corporation controlled by its shareholders in exchange for stock or cash. The original corporation then hiquidates, and its shareholders receive the assets retained plus the consideration received from the second corporation.

In the first pattern, the shareholders claim nonrecognition of gain or loss on their transfer of the assets to the second corporation under $\S 351$. In the second pattern, the corporation claims nonrecognition on the exchange with the second corporation under $\S 337$. In either case, the liquidated corporation does not recognize gain or loss on the liquidating distribution under $\S 336$, and the shareholders recognize their gam or loss on the liquidating distribution under $\$ \S 331$ and 1001 ineasured by the difference between the fair market value of the liquidating distribution and their adjusted basis in the stock of the liquidated corporation.

For a general discussion of the liquidation-reincorporation device, see Nicholson, Liquidation-Reincorporation, 335 TAX MNGM'T PORTFOLIO (BNA) (1976); BITTKER \& EuSTICE, supra note 6, at 17 11.05, 11.67, 14.54; Pugh, The F Reorganization: Reveille for a Sleeping Giant?, 24 TAX L. REV. 437 (1969).

56. Section 331 does not itself provide capital gain treatınent. By providing that a liquidating distribution will be treated by the sliarelıolders as payment in excliange for their stock, however, it brings the transaction within the "sale or exchange" requireinent of \& 1222, which defines the terms capital gain and capital loss. The sharelolders' gam or loss on the liquidating "ex- 
ing casls to the shareholders in the "liquidation." 57 An additional objective of solne liquidation-reincorporation transactions is the nonrecognition of gain at the corporate level under section 337 when the corporation wislies to sell a portion of its assets to unrelated third parties but wants to retain other operatimg assets in corporate form. Since section 337 applies only to a "complete liquidation," the liquidation-remcorporation sequence is used to make a partial liquidation of the business appear to be a coinplete liquidation. ${ }^{58}$ Other tax avoidance objectives might also prompt the liquidation-reincorporation transaction. 59

The Code does not address the liquidation-reincorporation problem, ${ }^{60}$ so the Internal Revenue Service and the courts have developed

change" will be capital in nature under $\S 1222$ if their stock in the liquidating corporation is a capital asset. See text accompanying notes 126-28 infra.

57. See, e.g., Ringwalt v. United States, 549 F.2d 89 (8th Cir.), cert. denied, 432 U.S. 906 (1977); Davant v. Commissioner, 366 F.2d 874 (5th Cir. 1966), cert. denied, 386 U.S. 1022 (1967); Ralph C. Wilson, Sr., 46 T.C. 334 (1966); James Armour, Inc., 43 T.C. 295 (1964); John G. Moffatt, 42 T.C. 558 (1964), affd, 363 F.2d 262 (9th Cir. 1966), cert. denied, 386 U.S. 1016 (1967); David T. Grubbs, 39 T.C. 42 (1962).

58. See, e.g., Telephone Answering Serv. Co., 63 T.C. 423 (1974), affd mem., 546 F.2d 423 (4th Cir. 1976), cert. denied, 431 U.S. 914 (1977) (discussed at text accoinpanying notes 62-65 infra); Werner Abegg, 50 T.C. 145 (1968), affd, 429 F.2d 1209 (2d Cir. 1970), cert. denied, 400 U.S. 1008 (1971); Ralph C. Wilson, Sr., 46 T.C. 334 (1966); Retail Properties, Inc., 23 T.C.M. (CCH) 1463 (1964). (Abegg, Wilson, and Retail Properties are discussed at note 86 infra.)

59. These include the recognition of a loss by the shareholders under $\$ 1001(c)$ if their stock in the liquidating corporation has declincd in value; a step-up in the tax basis for various assets of the business under $\S 1012$ if the assets have increased in value; elimination of the carnings and profits account; injection of preferred stock into the corporation's capitalization without the $\$ 306$ taint; and issuance of debt securities without dividend consequences. See, e.g., BITTKER \& EUsTICE, supra note 6, at 14-121 to 14-122.

60. The House version of the 1954 Code contained a provision designed to make it impossible to withdraw earnings and profits at capital gains rates or to obtain a step-up in the basis of corporate assets by using the liquidation-reincorporation device. The proposed bill provided that assets distributed to the shareholders in a liquidation and retamed by thein would be taxcd as dividends if $50 \%$ or more of the stock of the transferee corporation was owned by shareholders of the liquidated corporation and if 50\% or more of the assets of the liquidated corporation (excluding money and securities) were reincorporated within five years of the final liquidating distribution. If those conditions were met, the basis of the assets transferred would be the same as the basis to the transferor corporation. These provisions would be mapplicable if the taxpayer established that the principal purpose of the transaction was not tax avoidance. See H.R. Rep. No. 1337, 83d Cong., 2d Sess. A 129-31, reprinted in [1954] U.S. CODE CONG. \& AD. NEWS 4017, 426769 (describing proposed \& 357).

The Senate Finance Committee deleted this House provision without comment. The confer* ence report gave the following explanation for the deletion:

It is the belief of the managers on the part of the House that, at the present time, the possibility of tax avoidance in this area is not sufficiently serious to require a special statutory provision. It is believed that this possibihity can appropriately be disposed of by judicial decision or by regulation within the framework of the other provisions of the bill.

H.R. REP. No. 2543, 83d Cong., 2d Sess. 41, reprinted in [1954] U.S. CODE CONG. \& AD. NEws 5280,5301 .

Subsequently the Subchapter $C$ Advisory Group recommended that the hiquidationreincorporation problem should be dealt with by broadening the definition of a " $D$ " reorgamiza- 
their own reasons for denying the desired liquidation treatment. One of their theories is that a transaction is not a "complete liquidation" 61 if substantially the same sliareliolders continue to control the business assets of the liquidated corporation in uninterrupted corporate form.

A recent Tax Court case, Telephone Answering Service Co. v. Commissioner, ${ }^{62}$ illustrates the type of liquidation-reincorporation transaction in which it is appropriate to conclude that there has not been a complete liquidation. Teleplione Answering Service Co., Inc. (TASCO) operated a telephone answering service and also owned all of the stock of two subsidiaries, Houston and North American, which operated answermg services in otler parts of the country. An unrelated party offered to buy all of Houston's stock, but TASCO would have had a substantial gain on the sale. To avoid recognizing this gam, TASCO adopted a plan of complete liquidation, sold the Houston stock to the unrelated party for cash, transferred all of its directly owned operatimg assets to a newly-organized subsidiary ("New TASCO") in exchange for all of that corporation's stock, and then dissolved and distributed to its shareliolders tlie stock in New TASCO and North American plus the cash it had received from the sale of the Houston stock. TASCO realized a gain of $\$ 268,995$ on the sale of the Houston stock but claimed nonrecognition under section 337 .

The Tax Court found that the language of section 337

evidences an intent to require a bona fide elimination of the corporate entity and does not include a transaction in which substantially the same shareholders continue to utilize a substantial part of the directly owned

tion to include transactions in which the transferor or its shareholders own $50 \%$ or more of the transferee's stock rather than $80 \%$ or more as required by the existing statute. See Hearings Before the House Committee on Ways and Means on Advisory Group Recommendations on Subchapters $C, J$, and $K$ of the Internal Revenue Code, 86th Cong., 1st Sess. 597, 1030 (1959). See generally, Nicholson, Recent Developments in the Reincorporation Area, 19 TAX L. REV. 123 (1964). Congress has not acted in this area, however.

61. Although a number of Code provisions grant favorable tax treatment to a "complete liquidation," see I.R.C. $\$ \S 331-337$, the Code does not define the term. The House version of the 1954 Code would have defined the term as the distribution of substantially all of the corporate assets in redemption of all of the corporation's stock pursuant to a plan. Sce H.R. REP. No. 1337, 83d Cong,, 2d Sess. A112, reprinted in [1954] U.S. CODE CONG. \& AD. NEws 4017, 4250 (describing proposed $\S 336(\mathrm{~b})$, whicli defined the term "complete hquidation"). This definitional provision was dropped from the Senate version without explanation. The only regulation that defines a complete liquidation focuses as did the House definition on the divestiture by the liquidating corporation of all of its property and the redeinption of all of its stock:

To constitute a distribution in complete liquidation within the meaning of section 332, the distribution must be . . . made by the liquidating corporation in complete cancellation or redemption of all of its stock in accordance with a plan of liquidation . . . . A status of liquidation exists when the corporation ceases to be a going concern and its activities are inerely for the purpose of winding up its affairs, paying its debts, and distributing any reinaining balance to its slareholders.

Treas. Reg. \& 1.332-2(c) (1955).

62. 63 T.C. 423 (1974), affd mem., 546 F.2d 423 (4th Cir. 1976), cert. denied, 431 U.S. 914 (1977). 
assets of the same enterprise in uninterrupted corporate form. ${ }^{63}$

The business that TASCO had operated was continued uninterrupted by New TASCO, and the shareholders of TASCO owned more than eighty-four percent of New TASCO. ${ }^{64}$ The court held that because of this continuity of business and shareholder interest there had not been a complete liquidation. ${ }^{65}$

It is not clear what degree of contmumg shareholder interest is permissible in a "complete liquidation" $m$ which the enterprise is continued in corporate form. ${ }^{66}$ The Internal Revenue Service will not issue advance rulings regarding the applicability of section 337 "where more than a nominal amount of the stock (that is, more than 20 percent im value) of both the selling corporation and the purchasing corporation are owned by the same persons." ${ }^{17}$ Apparently the Service believes that if the shareholders of the liquidated corporation own less than twenty percent of the stock of the acquiring corporation, there is no possibility for the liquidation-reincorporation types of abuse.

This ruling policy establishes that a continuing shareholder interest in the transferee corporation of less than twenty percent will not preclude liquidation treatment, while Telephone Answering Service sug. gests that a continuing interest which exceeds eighty percent will render a liquidation "incomplete," at least absent a showmg that the transaction was undertaken for valid busmess reasons. ${ }^{68}$ No definitive standard exists for continuing interests in the twenty to eighty percent range, but the Internal Revenue Service has generally been unsuccess-

63. Id. at 433 (emphasis added).

64. The stock of a $15.7 \%$ shareholder was redeemed in a contemporaneous but apparently unrelated transaction. See id. at 429,436 .

65. Id. at 436.

The dissent argued that the majority was "preoccupied with a continuity of shareholdcr interest approach. The minimal (less than 15 percent) contmuity of assets is ignored. Even the House version of section 357 of the 1954 Code required, annong other things, a 50-percent continuity of assets before ignoring a purported liquidation." Id. at 438 (Sterrett, J., dissenting). This argument, however, overlooks the fact that the continuity of assets test of the proposed House provision would have excluded money and securities. See note 60 supra.

The issue of continuity of assets presumably would not arise in the context of the liquidation of a transferor corporation pursuant to a " $C$ " reorganization because in that situation substantially all of the assets of the transferor corporation must be transferred to the acquiring corporation. See note 6 supra and accompanying text.

66. The dissent in Telephone Answering Service criticized the majority for leaving "up in the air what magic percentage combination of shareholder and asset transfer will, in the future, imvalidate an asserted liquidation." 63 T.C. at 438 (Sterrett, J., dissenting).

67. Rev. Proc. 72-9, 1972-1 C.B. 718, 719.

68. The court noted in Telephone Answering Service that the "formation and utilization lof New TASCO] served no purpose other than masking a distribution as one im complete kquidation." 63 T.C. at 435.

The provision proposed by the House in 1954 to remedy the hquidation-remcorporation problem would not have precluded liquidation treatment, even if thc statutory degree of continuity of interest was exceeded, if the principal purpose of a transaction was not tax avoidance. See note 60 supra. 
ful in attacking liquidations in which the continuing interest is less than eighty percent. ${ }^{69}$ Since a " $C$ " reorganization in which the transferor corporation's shareholders own more than eighty percent of the acquiring corporation's stock is treated as a " $\mathrm{D}$ " reorganization, ${ }^{70} \mathrm{a}$ " $\mathrm{C}$ " reorganization ordinarily does not involve the degree of contimuing shareholder control that has thus far been held to preclude liquidation treatment in the liquidation-remcorporation cases.

\section{b. FEC's Interpretation of the Disassociation Requirement}

In considering whether section 337 should apply in the context of a reorganization, the Court of Claims in $F E C$ looked to the definition of a complete liquidation set forth in Pridemark, Inc. v. Commissioner, ${ }^{71}$ a liquidation-reincorporation case decided by the Fourth Circuit. Pridemark held that, to have a complete liquidation, "[t]lie corporation must have ceased to be a going corporate concern, or if the enterprise is continued in corporate form, the shareholder must have disassociated himself from it." 72

In Pridemark the court found that the corporation liad ceased to be a going concern, and it did not discuss its dictum that shareholder disassociation is necessary if the enterprise is continued in corporate form. ${ }^{73}$ The Court of Claims in $F E C$ interpreted the dictum to mean that, if the business is continued in corporate form, a coinplete liquidation cannot occur unless all of the shareholders completely terminate their interests in the business. ${ }^{74}$ There is no support for this conclusion.

69. See BiTTKER \& EUSTICE, supra note 6, at 14-128.

70. I.R.C. $\$ 368(\mathrm{a})(2)(\mathrm{A})$.

71. 345 F.2d 35 (4th Cir. 1965).

72. Id. at 41 (citing Treas. Reg. $§ 1.332-2$ (c) (1955)) (eunphasis added).

The Court of Claims' definition of a complete liquidation in $F E C$ was almost identical:

[A] complete liquidation, as the tax law knows it, mvolves either the dissolution of a business conducted in corporate form, or the planned disassociation of the shareholders

from the business if the enterprise continues. See Treas. Reg. $\S 1.332-2$ (c) (1955). 548 F.2d at 928.

73. Treas. Reg. § 1.332-2(c) (1955), cited in both Pridemark and FEC as support for the disassociation requireinent, makes no reference to any such requirement. See note 61 supra, which quotes this regulation in relevant part.

74. In one of its FEC briefs, the government noted that Pridemark had analogized a complete liquidation to the sharelolders' selling their stock for cash. Brief for the Defendant, $F E C$, supra note 28, at 15-16 (quoting Pridemark, 345 F.2d at 41). The Court of Claims apparently agreed with this analogy, for it stated that the transaction in question might lave constituted a liquidation if FEC had received casl in exchange for its assets and liad distributed the cash to its shareliolders. 548 F.2d at 928 .

Pridemark derived its analogy of a complete liquidation to a sale of stock for cash from a 1924 Senate Finance Committee Report explaining the legislation that first extended capital gains treatinent to shareholders who received liquidating distributions. See 345 F.2d at 41 (citmg S. ReP. No. 398, 68th Cong., 1st Sess. 12 (1924), reprinted in 1939-1 (Part 2) C.B. 266, 274 (explaining Internal Revenue Bill of 1924, § 201(c) (now I.R.C. § 331))). The implication that a sale of the corporate assets is required for a complete liquidation is misleading, for "it is well established that a distribution in kind is equally efficacious." BITTKER \& EUSTICE, supra note 6, at 11-5. 
Other decisions citing the Pridemark dictum have assumed that it refers to the requirement that a controlling interest must be relinquished. ${ }^{75}$

\section{The Compatability of the Continuity-of-Interest and the Disassociation Requirements in FEC and General Housewares}

In FEC and General Housewares the continuity-of-interest requireinent for a reorganization was satisfied because the transferor corporation and its shareholders received primarily voting stock in the acquiring corporation or its parent. In both cases, however, the stock that the shareholders received in the liquidating distribution represented less than a one percent interest in the acquiring corporation or its parent. This degree of control is far less than the twenty percent maximum allowed by the Internal Revenue Service in rulimgs issued under section $337 .^{76}$ Thus, far from illustrating a conflict between the requireinents of a reorganization and those of a coinplete hquidation, $F E C$ and General Housewares illustrate the zone in which the continuity-of-interest requirement of a reorganization and the disassociation requirement of the liquidation-reincorporation cases may both be satisfied in a single transaction.

\section{B. The Significance of the "Either Reorganization or Liquidation" Inquiry in Other Cases}

In $F E C$ the government cited only liquidation-reincorporation cases in support of its theory that reorganizations and liquidations are mutually exclusive. ${ }^{77}$ While the Court of Claims recognized that those cases were not controlling, ${ }^{78}$ it found thein to be relevant because the government's inutual exclusivity theory explained the results in those

75. See, e.g., Simon Trust v. United States, 402 F.2d 272 (Ct. Cl. 1968) (Nichols, J., who also wrote the $F E C$ opinion), in which the Court of Claims noted with apparent approval the way in which the government paraphrased the Pridemark dictuin: "Defendant says that a transaction involving a liquidation and reincorporation cannot be treated as a complete liquidation unless the business of the liquidated corporation is discontinued, or the controlling shareholders have disassociated themselves from it." Id. at 279 (emphasis added). In Simon Trust the court found that the business of the liquidated corporation was discontinued and therefore did not discuss the disassociation requirement.

76. See note 67 supro and accompanying text.

77. See text accompanying notes 31-32 supra and cases cited at note 32 supra. All of the cited cases involved a liquidation coupled with a transfer of part of the assets of the liquidated corporation to another corporation that was owned solely by the shareholders of the hiquidated corporation. The Tax Court reclassified the transactions as " $D$ " reorganizations. In one case, the Fifth Circuit held that the transaction in question constituted an " $F$ " as well as a " $D$ " reorganization. Davant v. Commissioner, 366 F.2d 874 (5th Cir. 1966), aff $g$ in relevant part 43 T.C. 540 (I965), cert. denied, 386 U.S. 1022 (1967).

78. The court agreed with FEC that the instant case was distinguishable because the sharelolders relinquished control of the assets transferred to the Whittaker subsidiary. 548 F.2d at 927. 
cases. The court also noted that the theory "seems to have been our court's unstated premise" in deciding two other liquidationreincorporation cases. ${ }^{79}$

The Court of Claims misconstrued the significance of the "either reorganization or liquidation" nature of the mquiry in the cases it rehed on, for those cases dealt with whether a liquidation-remcorporation should be reclassified as a reorganization in order to prevent tax avoidance. ${ }^{80}$ Courts have held in the liquidation-reincorporation con-

79. Id. (citing Mitchell v. United States, 451 F.2d 1395 (Ct. Cl. 1971), and Simon Trust v. United States, 402 F.2d 272 (Ct. Cl. 1968)).

Both Mitchell and Simon Trust involved the transfer of assets from one corporation to another corporation owned by substantially the same shareholders and the subsequent liquidation of the first corporation. In both cases there were vahid business reasons for carrying on the business in separate corporations and for liquidating the first corporation. In each case the Court of Claims held (1) that there was a coinplete hiquidation because the business of the liquidated corporation was discontinued and (2) that the transaction did not constitute a " $D$ " reorganization. Accordingly, the distributions to the shareholders were treated under $\S 331$ as in full payinent in exchange for their stock, and their gain was capital in nature.

80. It was crucial in Tax Court cases for the government to establish that the transaction in question satisfied the requirements of a reorganization because the Tax Court had held in Joseph C. Gallagher, 39 T.C. 144 (1962), that a reincorporation could be challenged only by classifying it as a reorganization:

Congress intended . . . that this problen of the continuation of a business must be dealt with, if at all, under the reorganization sections. Since these facts do not fall within the careful language of those sections, the distributions should be treated as payment in exchange for the stock [i.e., as distributions in conıplete liquidation under \$ 331].

Id. at 163 (enphasis added). This position was arguably more restrictive than Congress had intended, however, for in declining to include a specific statutory provision to deal with the hiquidation-reincorporation problent in the bill which becalne the 1954 Code, the conference committee had implied that the courts had considerable leeway to attack the problem. See note 60 supra.

In Telephone Answering Serv. Co., 63 T.C. 423 (1974), affd mem., 546 F.2d 423 (4th Cir. 1976), cert. denied, 431 U.S. 914 (1977) (discussed at text accompanying notes 62-65 supra), the Tax Court impliedly rejected the position it had taken in Gallagher by denying liquidation treatment on the theory that there was not a complete hiquidation without deciding whether there was also a reorganization. See id. at 432 n.4. The dissent argued that the court should have followed its prior decisions:

Since the transaction then does not fall within the reorganization provisions, which are designed to cover the instances of the continuation of an existing business through a liquidation coupled with an intercorporate transfer, it follows under the teachings of prior case law that the transaction nust, perhaps by definition of terms, be treated as a liquidation.

Id. at 437 (Sterrett, J., dissenting).

It is significant that the government can now attack a liquidation-reincorporation transaction in the Tax Court without having to classify the transaction as a reorganization because it is frequently impossible to fit sucl transactions within the statutory requirements of a reorganization. The Internal Revenue Service has often atteinpted to classify liquidation-reincorporation transactions as "D" reorganizations (transfers of assets to controlled corporations, see I.R.C. \& $368(a)(1)(D)$ ), but the 1954 clianges in the statutory definition of a " $D$ " reorganization preclude application of that provision to many transactions. In a " $D$ " reorganization the transferee corporation must acquire substantially all of the assets of the transferor corporation, $i d . \S 354(\mathrm{~b})(1)(\mathrm{A})$, and the transferor corporation inust in turn distribute the stock or other property received in the reorganization as well as its other property in pursuance of the plan of reorganization, id. \& $354(\mathrm{~b})(\mathrm{l})(\mathrm{B})$. To find a " $\mathrm{D}$ " reorganization in the hquidation-reincorporation context, a court 
text that, if a reorganization provision directly conflicts with a liquidation provision, the former prevails. ${ }^{81}$ Since the tax avoidance goals of a liquidation-reincorporation depend on the apphication of the liquidation provisions, ${ }^{82}$ inany such goals are foreclosed automatically if the government can establish that the requirements of a reorganization are satisifed. For example, if a liquidation-remcorporation transaction is deemed to be a reorganization, sections 354 and 356 apply at the sharelolder level rather than section 331, and thus distributions of boot to the shareholders may under appropriate circumstances be taxed as dividends. ${ }^{83}$ Other tax avoidance goals may be similarly defeated if the transaction is held to constitute a reorganization. ${ }^{84}$

may have to interpret these requirements broadly. See, e.g., James Armour, Inc., 43 T.C. 295 (1964) ("substantially all" requirement of $\S 354(\mathrm{~b})(\mathrm{l})(\mathrm{A})$ applied to the operating assets of the busmess and not to hquid assets that were not necessary to the conduct of the business; actual exchange of stock unnecessary under $\S 354(\mathrm{~b})(1)(B)$ because the shareholders owned $100 \%$ of both corporations). A few courts have found that hquidation-reincorporation transactions satisfy the requirements of an " $F$ " reorganization (mere change in identity, form, or place of organization, I.R.C. $\$ 368(a)(1)(F)$ ), but in those cases the requirements for a " $D$ " reorganization were probably also inet. See, e.g., Davant v. Commissioner, 366 F.2d 874 (Sth Cir. 1966), cert. denied, 386 U.S. 1022 (1967).

81. See, e.g., American Mfg. Co., 55 T.C. 204, 217 (1970).

82. See notes 56-59 supra and accompanying text.

For some purposes, however, reorganization treatunent may be more advantageous to the taxpayer than liquidation treatment. For example, if $\S 1245$ or $\S 1250$ property is transferred pursuant to a reorganization, depreciation is recaptured only to the extent that gain is requircd to be recognized pursuant to $\$ 361($ b). See I.R.C. $\$ \$ 1245(b)(3), 1250(d)(3)$. Sections 1245 and 1250 override $\S 337$, however. Treas. Reg. $\$ \S 1.1245-6(b)(1971), 1.1250-1$ (c)(2) (1971).

83. That $\S 356$ is applicable does not necessarily mean that distributions of boot will be taxed to the shareholders as dividends.

Distributions are not taxed under $\$ 356$ unless the shareholder realizes a gain on the distribution. To avoid this limitation of $\S 356$, the Fifth Circuit held in one liquidation-rcincorporation transaction that was reclassified as a reorganization that the distribution of boot to the shareholders was "functionally unrelated" to the reorganization. Davant v. Coinmissioner, 366 F.2d 874, 888 (5th Cir. 1966), cert. denied, 386 U.S. 1022 (1967). Under this rationale the distribution was taxcd to the sliareholders as a dividend under $\S 301$ measured by the earnings and profits of both corporations.

Even if the shareholder realizes a gain on a distribution, the gain is not autounatically taxed as ordinary income under § 356. See Rev. Rul. 74-515, 1974-2 C.B. 118; Rev. Rul. 74-516, 1974-2 C.B. 121. Scction 356(a)(2) provides that gain recognized by the shareholder nust be trcated as a dividend to the extent of his ratable share of post-1913 earnings and profits if the exchange "has the effect of the distribution of a dividend." In the typical liquidation-reincorporation whcre there is minimal shift in ownership, distributions may be equivalent to dividends. Sce Trcas. Reg. $\$ 1.331-I$ (c) (1955). Any gain in excess of the shareholder's ratable share of earnings and profits is treated as gain from the exchange of property (i.e, as capital gain unless the taxpayer is a dealer in securities). I.R.C. \$ 356(a)(2). See generally BlTTKER \& EUSTICE, supra note 6, at 1491 to I4-93; BITTKER \& EustiCe Supp., supra note 50, at S14-27 to S14-29.

84. For example, the transferee's basis in assets acquired in a reorganization is the sane as the basis of the assets in the hands of the transferor corporation increased by any gain recognized to the transferor. I.R.C. $\$ 362(\mathrm{~b})$. Thus the transferee corporation obtains at most a linnited stepup in basis for assets acquired in a reorganization. Also, the shareholders cannot rccognize a loss on the stock exclranged in a reorganization. Id. $\$ \S 354(\mathrm{a}), 356(\mathrm{c})$.

If the liquidation-reincorporation is held to be a reorganization, $\S 361$ ratlier than $\S 337$ or $\S$ 351 , see note 55 supra, prevents the recognition of gain or loss by the liquidating corporation or its 
If a transferor corporation makes sales to third parties, no reorganization provision conflicts with and overrides section 337. A few cases have denied the applicability of section 337 to sales to third parties where a hquidation-reincorporation was deemed to be a " $\mathrm{D}$ " reorganization, ${ }^{85}$ but those cases involved partial liquidations of a business. ${ }^{86}$ Thus the hiquidation-reincorporation cases do not establish that section 337 can never apply to sales to third parties in the context of a reorganization. $^{87}$

shareholders on the transfer of its operating assets to the transferee corporation. Even though all three sections are nonrecognition provisions, the tax consequences may in sone cases differ depending on which section is applicable. For example, if one of the parties to a reorganization is a foreign corporation, gain or loss realized on a $\$ 351$ or a $\$ 361$ exchange must be recognized unless the corporation obtains a ruling that the exchange is not in pursuance of a plan having as one of its principal purposes the avoidance of federal incoine tax. I.R.C. \& 367; see, e.g., Werner Abegg, 50 T.C. 145,158 (1968), affd, 429 F.2d 1209 (2d Cir. 1970), cert. denied, 400 U.S. 1008 (1971); Retail Properties, Inc., 23 T.C.M. (CCH) 1463, 1470-73 (1964). Section 367 does not apply to a $\S$ 337 exchange, however. See I.R.C. \& 367(a).

85. See Werner Abegg, 50 T.C. 145 (1968), affd, 429 F.2d 1209 (2d Cir. 1970), cert. denied, 400 U.S. 1008 (1971); Ralph C. Wilson, Sr., 46 T.C. 334 (1966); Retail Properties, Inc., 23 T.C.M. (CCH) 1463 (1964).

86. See text accompanying note 58 supra.

In Ralph C. Wilson, Sr., 46 T.C. 334, 351-52 (1966), and Retail Properties, Inc., 23 T.C.M. (CCH) 1463, 1473 (1964), the Tax Court denied $\S 337$ treatment because there had not been a coinplete liquidation. In Werner Abegg, 50 T.C. I45 (1968), aff d, 429 F.2d 1209 (2d Cir. 1970), cert. denied, 400 U.S. 1008 (1971), however, the Tax Court stated that $\$ 337$ did not apply because the liquidation provisions do not apply when a reorganization occurs:

The respondent correctly determined that a reorganization was effected under section 368(a)(l)(D).

Since a reorganization occurred, the tax consequences are to be governed by the provisions of the Code dealing with reorganizations, sections 354 to 368, and not those dealing with liquidations, sections 331 to 346. Commissioner v. Morgan, 288 F.2d 676 (C.A. 3, 1961), reversing 33 T.C. 30 (1959), certiorari denied 368 U.S. 836, rehearing denied 369 U.S. 826; Liddon v. Commissioner, 230 F.2d 304 (C.A. 6, 1956); affirming on this point 22 T.C. 1220, certiorari denied 352 U.S. 824; David T. Grubbs, 39 T.C. 42 (1962). It follows that . . . [the liquidated corporation's] gaim of \$932,701.27 realized npon sales of stock is not subject to nonrecognition under section 337 as in a liquidation, but is to be recognized under section 1002 .

Id. at 157 (footnote omitted) (eniphasis added). The cases cited as support for the statement that the liquidation provisions cannot apply in the context of a reorganization dealt with whether the liquidation or the reorganization provisions would apply at the shareholder level. Those cases did not consider whether a hquidation provision could apply if it did not conflict with a reorganization provision. In affirming the Tax Court decision, the Second Circuit merely stated:

[The plaintiff] does not dispute that if the result of the 1957 transactions had been achieved by a straightforward reorganization under $\$ 368(a)$ (l) (D), the gams realized by ... [the liquidated corporation] on sales of securities [to unrelated third parties] would not come under the nonrecognition shelter of $\$ 337 \ldots$.

429 F.2d at 1212.

87. Recognizing that $\S 337$ could be applied in the context of a reorganization, in 1959 the Subchapter C Advisory Group proposed that $\$ 337$ be amended to provide that it would not apply to a sale or exchange imvolving a transfer of property to which a "C," " $D$," or " $F$ " reorganization applied. The proposal was not adopted. See note 117 infra and accompanying text. 


\section{Contexts in Which Liquidation and Reorganization Provisions Coexist}

The mutual exclusivity theory relied on by the Court of Claims in $F E C$ is further weakened by exainples of single transactions in which the reorganization and liquidation provisions have both been applied. ${ }^{88}$

When a transferor corporation liquidates as part of a " $C$ " reorganization and distributes all of its assets to its shareholders in exchange for their stock, no reorganization provision explicitly exempts the corporation from the general rule ${ }^{89}$ that gain or loss must be recognized on a sale or exchange. Yet the transferor corporation clearly does not recognize gain or loss, and the applicable statutory exception is generally assumed to be section 336, a hquidation provision, which provides that "no gam or loss shall be recognized to a corporation on the distribution of property in partial or complete liquidation." 90

88. As one such example, the plaimtiff in General Housewares noted that $\$ 356$ applies only to shareholders who receive boot in addition to stock in the acquiring corporation or its parent. It argued that if a transferor corporation distributes only cash to some of its shareholders im a liquidation pursuant to a reorganization, the taxation of those shareholders must be governed by $\S 331$, a liquidation provision. Trial Brief for the Plaintiff at 26-27. This reasoning is not persuasive, however, for such distributions are treated as redemptions under $\S 302$. See note 12 supra.

89. I.R.C. \& 1001 (c).

90. The district court in General Housewares assumed that $\$ 336$ accords nonrecognition treatment to the transferor corporation when it liquidates pursuant to a reorganization. See note 42 supra and accompanying text. In discussing the assertion made by the Court of Claims in $F E C$ that liquidation and reorganization provisions cannot coexist, the supplement to the Bittker and Eustice treatise makes a similar assumption: "Presumably the court did not intend to hold that the transferor-corporation inust recognize gain when it distributes the transferce's stock to its shareholders in complete hquidation pursuant to the plan ( $\$ 336$ clearly would seem to apply to protect the distributing corporation here. . .)." BITTKER \& EUSTICE Supp., supra note 50, at S1424 (einphasis added).

The government argued in General Housewares that $\$ 336$ could not be the applicable nonrecognition provision in a hquidation pursuant to a reorganization because it was first enacted as part of the 1954 Code, whereas the reorganization provisions are a product of the 1921 Revenue Act. Reply Brief for the Defendant at 7-8. This argument, however, overlooks that the basic rule of $\S 336$ was applied under the 1921 Revenue Act by Treas. Reg. 62, art. 548 (1921), which provided: "No gain or loss is realized by a corporation from the mere distribution of its assets in kind upon dissolution, however they may have appreciated or depreciated in value since their acquisition." The regulations under the Internal Revenue Code of 1939 contained a similar provision. See Treas. Reg. 103, \& 19.22(a)-21 (1939).

The government's argument that $\S 336$ is not the applicable nonrecognition provision is also weakened by the fact that no other nonrecognition provision could apply.

Section 311(a) provides: "[N]o gain or loss shall be recognized to a corporation on the distribution, with respect to its stock, of . . property." The regulations, however, state that $\& 336$ rather than $\S 311$ is intended to apply to liquidating distributions. See Treas. Reg. $\S 1.311-1$ (a) (1955).

The literal language of $\S 354(a)(1)$ inight also seem to accord nonrecognition treatunent to liquidating distributions pursuant to a reorganization: "No gaim or loss shall be recognized if stock or securities in a corporation a party to a reorganization are, in pursuance of the plan of reorganization, exchanged solely for stock or securities in such corporation or in another corporation a party to the reorganization." While $\S 354$ might apply if the transferor corporation distributed solely stock in the acquiring corporation or its parent to its shareholders, that provision would not 
Another type of transaction in which hquidation and reorganization provisions coexist is a parent-subsidiary inerger. If an eighty percent subsidiary is merged into its parent corporation, the combination may in soine cases be treated both as a coinplete liquidation under section $332^{91}$ and as a reorganization. ${ }^{92}$

The Second and Sixth Circuits, the Court of Claims, the Tax Court, and the Internal Revenue Service have all held that such a 1nerger may be treated as an " $F$ " reorganization for purposes of determining whether post-merger net operating losses may be carried back against pre-merger profits of the former subsidiary even though section 332 also apphes to the inerger. ${ }^{93}$ In Performance Systems, Inc. v. United States, ${ }^{94}$ the district court explained:

This Court holds that the reorganization and liquidation provisions of Subchapter $C$ of the Internal Revenue Code are not mutually exclusive, and a transaction qualifying as an " $F$ " reorganization is not precluded from the benefits conferred upon " $F$ " reorganizations under Section 381(b) of the Internal Revenue Code merely because the transaction also qualifies under Section 332 of the Internal Revenue Code. ${ }^{95}$

The Tax Court has also suggested that a merger might be treated as a liquidation for the purpose of determining the basis of the assets transferred and as an " $A$ " reorganization for other purposes. ${ }^{96}$ Finally, a

accord nonrecognition treatment to the transferor corporation on the distribution of boot. Thus some other nonrecognition provision must apply to a transferor corporation in at least some hquidations pursuant to a reorganization.

The government argued in General Housewares that it is $\S 361$ which protects the transferor corporation when it makes a liquidating distribution pursuant to a "C" reorganization. Reply Brief for the Defendant at 8. Section 361(a) states: "No gain or loss shall be recognized if a corporation a party to a reorganization exchanges property, in pursuance of the plan of reorganization, solely for stock or securities in another corporation a party to the reorganization." (Emphasis added.) In liquidating, the transferor corporation normally exchanges property for its awn stock, and thus the literal language of $\$ 361$ would not appear to be met in an exchange with the corporation's own shareholders.

91. Section 332 provides that under certain conditions gain or loss shall not be recognized by a parent corporation on the receipt of property distributed in complete hquidation of a subsidiary.

92. Liquidation versus reorganization treatment can have a number of important tax consequences, such as determining the basis of the assets transferred, whether gain or loss will be recognized on the transfer, and whether post-merger net operating losses may be carried back against pre-merger profits of the former subsidiary. See generally Freling \& Martin, Current Reorganization Techniques, 55 TAXES 852, 869-71 (1977); Krane, Current Problems in Acquisitive Reorganizations, 51 TAXES 737, 755-57 (1973); McManus, Judicial Law-Making: The Liquidation of a Corporation Treated as an F Reorganization, 2 J. CORP. TAX. 273 (1975); Seago, The Upstream Merger: Liquidation of a Subsidiary or an F Reorganization?, 53 TAXES 88 (1975).

93. See Aetna Cas. \& Sur. Co. v. United States, 568 F.2d 811 (2d Cir. 1976); Performance Syss., Inc. v. Umited States, 501 F.2d 1338 (6th Cir. 1974) (per curiam); Movielab, Inc. v. United States, 494 F.2d 693 (Ct. Cl. 1974); Eastern Color Printing Co., 63 T.C. 27 (1974); Rev. Rul. 75561, 1975-2 C.B. 129.

94. 382 F. Supp. 525 (M.D. Tenn. 1973), affd per curiam, 501 F.2d 1338 (6th Cir. 1974).

95. Id. at 534 (emphasis added).

96. See Kansas Sand and Concrete, Inc., 56 T.C. 522, 530 (1971), affd per curiam, 462 F.2d 805 (10th Cir. 1972): 
parent-subsidiary merger may be treated as a liquidation under section 332 to the parent but as a reorganization to the minority shareholders. ${ }^{97}$

\section{Summary}

The theory that complete hquidations and reorganizations are mutually exclusive is not supported by the Court of Claims' rationale in $F E C$ and is inconsistent with the law in related areas. There is no necessary conflict between the requirements of a reorganization and those of a complete liquidation, at least when the shareholders of the liquidated transferor corporation do not maintain a controlling interest in the acquiring corporation or its parent. Soine cases have employed an "either reorganization or liquidation" imquiry in determining whether reorganization provisions should override conflicting liquidation provisions in the liquidation-remcorporation context. Prior to $F E C$, however, no case explicitly held that a liquidation provision can never apply in a reorganization, and in fact reorganization and hquidation provisions do coexist in some situations. Thus the mutual exclusivity theory is not a valid basis for denying section 337 treatment to a transferor corporation that liquidates pursuant to a " $\mathrm{C}$ " reorganization.

\section{The Theory that Section 337 Is Linked to Section 331}

The mutual exclusivity theory was not the government's only ground for arguing that section 337 was inapphicable in FEC and General Housewares. In botll cases the government also contended that section 337 implicitly requires immediate recognition under section $331^{98}$ of any gam realized by the shareholders on the liquidating distribution. In a reorganization, recognition at the shareholder level is ordinarily governed by sections 354 and 356 rather than by section 331 . Froin this the government concluded that section 337 was not intended to apply to a liquidation that is undertaken pursuant to a reorganization. An alternative argument made by the government in General Housewares, though not in $F E C$, was that if section 337 apphies at the corporate

[O]ur decision today does not necessarily require that a transaction considered a distribution in complete liquidation within the meaning of section 332 for the purpose of applying section $334(\mathrm{~b})(2)$ may not be considered a reorganization under section $368(\mathrm{a})(1)(\mathrm{A})$ for soine other unrelated purpose.

But cf. American Mfg. Co., 55 T.C. 204, 220 (1970) (liquidation treatment under $\$ 332$ may be precluded when the liquidation is pursuant to a " $D$ " reorganization).

97. See May B. Kass, 60 T.C. 218 (1973), affd mem., 491 F.2d 749 (3d Cir. 1974); Treas. Reg. \$ 1.332-2(d) (1955).

98. Section 331 is technically not a recognition provision. See text accounpanying notes 124-30 infra. In analyzing the government's arguinent, however, this Part will retain the governinent's terminology. 
level the shareholders must recognize their gain, if any, under section 331.

\section{A. The Theory that Section 337 is Inapplicable When Section 331 Does Not Apply}

There is no explicit statutory requirenent that any gain realized by the shareholders on a liquidating distribution inust be recognized under section 331 for section 337 to apply. The government based this arguinent on its interpretation of the legislative history and the purpose of section 337. The Court of Claims did not refer to this arguinent in $F E C$, presumably because it held for the government on the mutual exclusivity theory. The district court summarily rejected the argument in General Housewares without analyzing the government's position. ${ }^{99}$ The following will deinonstrate that the government's reasoning is unsupportable.

\section{The House Committee Report}

In revising the Internal Revenue Code in 1954, both the House and the Senate proposed legislation designed to grant nonrecognition treatment to a corporation that sold assets while in the process of liquidating. A committee report explaining the House proposals stated:

[Y]our committee has provided that if a corporation in process of liquidation sells assets there will be no tax at the corporate level, but any gain realized will be taxed to the distributee-shareholder, as ordinary incoine or capital gain depending on the character of the asset sold. ${ }^{100}$ The government argued in its FEC and General Housewares briefs that the italicized phrase shows that Congress intended for section 337 to apply to a coinplete liquidation only when the shareliolders recognize their gain, if any, under section $331 .{ }^{101}$

The government's argunient overlooks the fact that the liquidation proposals described in the House committee report differed substantially froin the Senate provisions whicli were actually enacted as sections 331 and 337 of the Code. The statement in the House committee

99. The opinion stated merely:

This court holds that the immediate recognition of gain at the shareholder level is not an "implicit" requirement for the application of Section 337. The clear intent of Congress in enacting Section 337 was to remove the need to make a formalistic determination as to whether the corporation or its sharelolders sold corporate property during the course of a liquidation. Neither Section 337 nor its legislative history requires the immediate recognition of gain by the shareliolders of the liquidating corporation in order for the section to apply.

Slip op. at 28 (footnote omitted).

100. H.R. REP. No. 1337, 83d Cong., 2d Sess. 39, reprinted in [1954] U.S. Code Cong. \& AD. NEws 4017, 4064 (empliasis added), quoted in Brief for the Defendant, FEC, supra note 28, at 22 and Brief for the Defendant at 30,41, General Housewares.

101. Brief for the Defendant, FEC, supra note 28, at 22-23; Brief for the Defendant at 30-31, General Housewares. 
report that any gain realized would be taxed to the distributee-shareholder referred, not to the shareholders' recognition of their gain under section 331, but rather to the shareholders' recognition of the corporation's gain. Under the House proposals, any gain realized by the corporation on the sale of assets that was not recognized under the House analog of section $337^{102}$ would have been includable in the incoine of the distributee-shareholders in the year the liquidating distribution was received. ${ }^{103}$ The shareholders' basis in their stock would have been increased by the amount of this corporate gain recognized, ${ }^{104}$ and thus the shareholders' gain realized on the liquidating distribution would have been decreased (or their loss increased) by the amount of the corporate gain they were required to recognize. Whether the shareholders would have been required to recognize their gain or loss on receipt of the liquidating distribution would have been determined by a complex set of rules. ${ }^{105}$

The liquidation provisions actually enacted provide a completely different set of rules to govern the timing of the recognition of gain or loss realized by shareholders on a liquidating distribution. ${ }^{106}$ The legis-

102. Section 333(a), the analog of $\S 337$ proposed by the House, would generally have been more favorable to liquidating corporations. It would liave provided that a corporation would not recognize gain (but would recognize loss) on the sale of an asset after the adoption of a plan of partial or complete liquidation if the liquidation was completed within the taxable year in which the sale occurred or within the following taxable year. See H.R. REP. No. 1337, 83d Cong., 2d Sess. A106-07, reprinted in [1954] U.S. CODE CONG. \& AD. NEws 4017, 4244.

103. Id. at A106, reprinted in [1954] U.S. CODE CONG. \& AD. NEWS at 4244 (describing proposed House $\S 332(\mathrm{c})$ ). The character of this shareholder gain would have been the same as that recognized to the corporation absent the application of proposed \$333(a). Id.

104. Id. at A104, reprinted in [1954] U.S. CODE CONG. \& AD. NEWS at 4242 (describing proposed House \& 331(e)(3)).

105. Recognition would have depended on the relationship between the adjusted basis of the assets distributed ("X"), their fair market value ("Y"), and the adjusted basis of the stock with respect to which the distribution was inade (' $Z$ "), as shown by the following table:

\begin{tabular}{ll}
\multicolumn{1}{c}{ If } & \multicolumn{1}{c}{ Then } \\
\hline$X \& Y>Z$ & Gain recognized \\
$Z>Y$ & Loss recognized \\
$Y \geq Z>X$ & Gain or loss not recognized
\end{tabular}

See id. at A101-02, reprinted in [1954] U.S. CODE CONG. \& AD. News at $4239-40$ (describing proposed House § 331(b)-(d)).

106. The Senate Finance Committee report gave only the following explanation of why it rejected the proposed House provisions:

[Y] our committee has made a substantial change in the approach adopted by the House with respect to corporate hiquidations generally. Under the House provisions, part II

limited the amount subject to tax at the time of complete or partial liquidation of a corporation to the excess of the basis of assets in the hands of the liquidating corporation over the basis of the stock in the shareliolder's hands. This approach does not appear in part II of your committee's bill. In lieu of this your committee has in large ineasure returned to the basic provisions relating to liquidations under the 1939 code.

S. REP. No. 1622, 83d Cong., 2d Sess. 254, reprinted in [1954] U.S. CODE CONG. \& AD. NEwS 4621, 4891-92. The conference report did not indicate why the Senate hquidation provisions rather than the House provisions were adopted. See H.R. REP. No. 2543, 83d Cong., 2d Sess., reprinted in [1954] U.S. CODE CONG. \& AD. News 5280. 
lative history of the proposed House provisions therefore is not a reliable indicator of the meaning of sections 337 and 331 as enacted.

\section{The Congressional Purpose of Eliminating Double Taxation}

As additional support for its theory that section 337 should not apply unless section 331 also applies, the government argued that Congress enacted scction 337 to eliminate double taxation. ${ }^{107}$ Since double taxation would not occur unless the shareholders recognize their gain on the liquidating distribution, the government concluded that Congress implicitly intended for section 337 to apply only when the shareholders are taxed under section $331 .^{108}$

While some cases ${ }^{109}$ and commentators ${ }^{110}$ have assumed that one of the congressional purposes of section 337 was to eliminate double taxation, the Supreme Court las rejected such reasoning, stating: "There is nothing in the legislative history indicating that \& 337 was enacted in order to eliminate 'double taxation' as such. Rather, the statute was designed to eliminate the formalistic distinctions recognized and perhaps encouraged by the decisions in Court Holding and Cumberland." "11 The Tax Court ${ }^{112}$ and the Internal Revenue Service ${ }^{113}$ have likewise rejected the theory that section 337 was intended to elimi-

107. Double taxation refers to the taxation of income at the corporate level and then again at the shareholder level if the incoine is distributed to the shareholders. See generally BITTKER \& Eustice, supra note 6, at ๆ 1.03 .

108. See Brief for the Defendant, $F E C$, supra note 28, at 23; Brief for the Defendant at 31 , General Housewares.

109. See, e.g., Pridemark, Inc. v. Commissioner, 345 F.2d 35, 44-45 (4th Cir. 1965); Kent Mfg. Corp. v. Commissioner, 288 F.2d 812, 815 (4th Cir. 1961); Central Tablet Mfg. Co. v. United States, 339 F. Supp. 1134, 1137 (S.D. Ohio 1972), rev'd, 481 F.2d 954 (6th Cir. 1973), aff'd, 417 U.S. 673 (1974); Kinney v. United States, 73-1 U.S. Tax Cas. 80,128, 80,129 (N.D. Cal. 1972); Manilow v. United States, 315 F. Supp. 28, 32 (N.D. Ill. 1970).

110. See, e.g., Grant, Some Piffalls in a One-Year Liquidation, 12 U.C.L.A. L. REv. 1135 (1965); Note, The Tax Benefit, Recoveries, and Sales of Property Under Section 337, 9 WM. \& MARY L. REV. 476, 482 (1967).

111. Central Tablet Mfg. Co. v. United States, 417 U.S. 673, 682 (1974) (einphasis added). The formalistic distinctions recognized in the Cumberland and Court Holding cases are discussed at text accompanying notes $134-48$ infra.

112. In Frank W. Verito, 43 T.C. 429 (1965), the Tax Court stated:

The purpose of the section [337] was not to eliminate one level of taxation. This could be done without the aid of section 337. . . The purpose of the section was aimed at eliminating the uncertainties attendant upon the Supreine Court decisions in Court Holding Co. and Cumberland Pub. Serv. Co. and to make inoot the question as to whether a sale of assets was accomplished by the corporation or its stockholders.

Id. at 439 (citation omitted).

113. At one time the Service disallowed $\S 337$ treatinent to an insolvent corporation whose hquidating distribution was entirely to creditors. One of its grounds for so holding was the belief that the purpose of $\S 337$ was to eliminate double taxation and that the provision therefore should not apply where there was no possibility that the proceeds from the sale of corporate assets would be taxed to the shareholders. Rev. Rul. 56-387, 1956-2 C.B. 189. The Service subsequently retracted this position, ruling that $\$ 337$ may apply irrespective of whether the shareholders realize a gain and hence are taxed on the liquidating distribution. Rev. Rul. 73-264, 1973-1 C.B. 178. 
nate double taxation. Thus the government's argument discussed in the preceding paragraph is based on an erroneous premise.

\section{The Statutory Exceptions to Section 337}

The government's argument that section 337 was intended to be linked to section 331 is also implicitly refuted by the statutory exceptions to section 337. Congress did not make section 337 inapplicable to all liquidations im which section 331 does not apply. Rather, section 337 is by its terms mapplicable only to liquidations im which either section $333^{114}$ or section $332^{115}$ applies at the shareliolder level or in which the liquidating corporation is collapsible. ${ }^{116}$

In 1959 the Subchiapter C Advisory Group recommended to Congress that it enact an additional statutory exception that would make section 337 inapplicable "to a sale or exchange involving a transfer of property to whicls section 368(a)(1) (C), (D), or (F) apphes." 117 The proposal was not enacted, lowever, and thus there is no statutory basis for the argument that section 337 cannot apply if the reorganization provisions rather than section 331 apply at the shareholder level. ${ }^{118}$

114. I.R.C. $\$ 337(\mathrm{c})(1)(B)$. Section 333 provides that if certain requirements are met a shareholder may elect not to recognize gain on distributions received in a complete liquidation of a corporation occurring within one calendar inonth.

115. Id. $\S 337(c)(2)$. This exccption applies if there is a complete liquidation of a subsidiary under $\S 332$ and in accordancc with the general basis rule of $\S 334(b)(1)$ the subsidiary's basis in the assets transferred carries over to the parent.

116. Id. $\S 337(\mathrm{c})(\mathrm{I})(\mathrm{A})$. A "collapsible corporation" is one "formed or availed of . . with a view to the sale or exchange of stock by its shareholders (whether $m$ liquidation or otherwise). . . before the realization by the corporation . . . of a substantial part of the taxable income to be derived from such property. . . ." Id. \& 341 (b)(1).

The legislative history does not indicate why the $\S 337$ (c) exceptions were enacted. See S. Rep. No. 1622, 83d Cong., 2d Sess. 259-60, reprinted in [1954] U.S. CODE Cong. \& AD. NEws 4621, 4897 (describing I.R.C. § 337(c)).

117. Hearings Before the House Committee on Ways and Means on Advisory Group Recommendations on Subchapters $C$, J, and $K$ of the Internal Revenue Code, 86tl Cong., 1st Sess. 585 (1959).

The Advisory Group stated:

Section 337 is designed to eliminate the corporate tax with respect to sales and exchanges in connection witl complete liquidations which involve taxable distributions to the slarelıolders. Liquidations incident to corporate reorganizations are not considered under the Code to be in connection with such complete liquidations as the property transferred in reorganization continues in corporate solution. For example, under some circunnstanccs sales or exchanges of corporate property to corporations controlled by the same interests may constitute reorganizations within the definition contained in section 368 (a) (1) (D); and in such situations, though liquidation distributions may be incident thereto, no gain or loss is recognized to the stockholders except wlere "boot" is received. In order to correlate section 337 and the reorganization provisions and prevent an improper overlap, it is recommended that the amendment of section 337 (c) initially proposed be revised so as to make the section expressly inapplieable to sales or exchanges involving transfers to which section 368 (a) (1) (C), (D), or (F) applies.

Id. at 534 .

118. The regulations likewise do not impose such a restriction. Treas. Reg. $\S 1.337-5$ (a) (1961) states that $\& 337$ (d), which contains special rules for certain minority shareholders, applies only with respect to distributions in complete liquidation under $\S 331$ and does not apply if $\$ 354$ or $\S 356$ applies, but the regulations do not similarly restrict the applicability of $\S 337$ (a). 


\section{B. The Theory that Section 331 Must Apply When Section 337 Applies}

As an alternative to the theory that section 337 is inapplicable when section 331 does not apply, the government argued in General Housewares that, if section 337 does apply to the transferor corporation in a reorganization, the shareholders inust recognize their full gain or loss under section $331 .{ }^{119}$ It based this theory primarily on the statutory scheine of the Code, reasoning that a "coinplete liquidation" to which section 337 applies inust be taxed to the shareholders as a "coinplete liquidation" under section $331 .{ }^{120}$ It also found support for its theory in a House committee report explaining the House analog of section 337. ${ }^{121}$

As discussed above, reliance on the House committee report is misplaced because the liquidation provisions proposed by the House were not enacted. ${ }^{122}$ The government's interpretation of the statutory scheine is also erroneous, as the district court concluded in General Housewares. ${ }^{123}$

Section 331(a)(1) provides that "[a]1nounts distributed in coinplete liquidation of a corporation shall be treated as in full payinent in exchange for the stock." The government apparently assuined that since a liquidating distribution is treated as an "exchange" the shareholders 1nust automatically recognize their gain or loss on the distribution. ${ }^{124}$ The assumption that an "exchange" is necessarily a taxable event is erroneous, however. ${ }^{125}$

The significance of the legislative creation of an exchange in section 331 is that the liquidating distribution is therefore treated as a sale

119. Requiring the shareholders to recognize their gain or loss under $\$ \S 331$ and 1001 , see text accompanying notes 124-30 infra, on distributions pursuant to a reorganization would in sone cases increase their immediate tax hability, since any gain that would ordinarily be deferred under $\S \S 354$ and 356 would be recognized at the time of distribution. Also, a corporate shareholder's tax hability might be greater if $\$ \S 331$ and 1001 rather than $\S 356$ (a)(2) (relating to distributions equivalent to dividends, see note 83 supra) applies because of the deduction for dividends received allowed corporations under $\$ 243$.

Ironically, however, application of $\S \S 331$ and 1001 rather than $\S \S 354$ and 356 would in some cases decrease the shareholders' tax hability because (1) loss realized on a liquidating distribution is recognized under $\S 1001$ but not under $\$ \$ 354$ and 356, see I.R.C. $\$ \S 1001$ (c), 354(a), 356(c), and (2) gain is generally capital in nature under $\S 331$ but may be ordimary income under $\S 356$, see notes 56 \& 83 supra.

120. See Brief for the Defendant at 37-44, General Housewares.

121. See id. at 40,41 \& n.5.

122. See notes 100-06 supra and accompanying text.

123. See note 48 supra and accompanying text.

124. See Brief for the Defendant at 38, General Housewares.

125. The Code provides nonrecognition treatment for several types of exchanges. See, e.g., I.R.C. $\$ \S 351-368$ (nonrecognition on exchanges pursuant to corporate organizations and reorganizations); $i d . \S 1031$ (nonrecognition on "like-kind" exclianges). 
of the shareholders' stock rather than as a dividend. ${ }^{126}$ Accordingly, the gain or loss that the shareholders realize on the liquidating distribution is measured by the difference between the value of the distribution and their adjusted basis in their stock ${ }^{127}$ and is capital in nature if their stock in the liquidating corporation is a capital asset. ${ }^{128}$

The relevant recognition provision is not section 331 but rather section 1001(c), ${ }^{129}$ which states: "Except as otherwise provided in this subtitle, the entire amount of the gam or loss, determined under this section, on the sale or exchange of property shall be recognized." In the context of a reorganization, sections 354 and 356 provide an exception to this general rule, and the shareholders do not recognize gain or loss on the liquidating "exchange" except to the extent of any boot distributed. ${ }^{130}$

\section{Summary}

Neither the Code nor the legislative history supports the theory that for section 337 to apply at the corporate level section 331 must apply concurrently at the shareholder level. The statutory exceptions to section 337 establish that section 337 generally may not apply when section 332 or section 333 applies at the shareholder level, but Congress has not enacted a specific proposal to inake section 337 inapphicable in the context of a reorganization. That part or all of the shareholders' gam may be deferred on a liquidating distribution pursuant to a reorganization should not necessarily preclude the application of section 337 , for the purpose of that provision was not to eliminate double taxation as such. ${ }^{131}$ Thus the government's theory discussed in this Part does not establish that section 337 should not apply concurrently with sections 354 and 356 in a hquidation that is undertaken pursuant to a reorganization.

126. See generally BitTKER \& EUSTICE, supra note 6, at $\$ 11.01$.

127. See I.R.C. \& 1001.

128. See id. § 1222. The term "capital asset" is defined in § 1221.

129. For taxable years beginning before 1977 , this provision was contained in $\S 1002$.

130. See, e.g., 3 STAND. FED. TAX REP. (CCH) I 2509.25 (1978):

Code Sec. 331 provides for the computation of gain or loss from the receipt of liquidation distributions. But gain or loss will not be recognized if the liquidation distribution is part of a tax-free reorganization exchange and it comes within the terms of the reorganization sections of the Code. This is so because, under Code Sec. 331, a liquidation distribution is treated as payment in "excliange" for the stock. And the fact that the exchange is also a liquidation distribution does not make it any the less a tax-free excliange if the reorganization provisions are complied witl. . . .

... [T] he general rule for computation of gain or loss on liquidation is subject to the specific rule that, in certain exchanges of stock for stock in reorganization, any gain as computed under other sections of the Code (Sec. 331, for example) is not recognized ....

131. For a further discussion of the significance of the tax consequences at the shareholder level in a liquidation pursuant to a reorganization, see notes 160-64 infra and accompanying text. 
IV

The Legislative Purpose of Section 337

The district court concluded in General Housewares that section 337 applied to the sales to third parties by the transferor corporation because the hiteral requirements of that provision were met and none of the government's counterarguments was persuasive. ${ }^{132}$ This holding is also supported by the congressional purpose behind section $337 .{ }^{133}$

\section{A. The Pre-1954 Tax Treatment of a Liquidation Coupled with a Sale of Corporate Assets}

Before the enactunent of section 337 in 1954, the tax consequences of a complete liquidation of a corporation coupled with a sale of the corporate assets depended on the form of the transaction. If the corporation sold the assets and distributed the proceeds to its shareholders im liquidation, the corporation recognized its gain or loss on the sale, ${ }^{134}$ and the shareholders recognized their gain or loss on the liquidating distribution. ${ }^{135}$ Since a corporation did not recognize gain or loss on the distribution of property im liquidation, however, ${ }^{136}$ the corporate tax could be eliminated if the corporation liquidated in kind and the shareholders sold the assets. The sharelolders still recognized their gain or loss on the liquidating distribution. ${ }^{137}$ Their basis in the property received was its fair inarket value at the time of the distribution, ${ }^{138}$ and they realized no further gain or loss if they subsequently sold the property for an amount equal to its fair market value at the time of distribution. ${ }^{139}$

Since a corporate sale of assets followed by a distribution of the proceeds to the shareliolders is economically imdistimguishable froin a distribution of the assets in kind followed by a sale by the shareholders, the pre-1954 rules exalted form over substance. Taxpayers who were aware of the rules could im theory avoid the corporate tax by distributing corporate assets in kind. But distributions in kind were awkward

132. See notes $40-48$ supra and accompanying text.

133. Surprisingly, neither the $F E C$ opinion nor the General Housewares opinion discussed the legislative purpose of $\S 337$ or whether that purpose would be served by applying the provision in the context of a " $\mathrm{C}$ " reorganization.

134. Int. Rev. Code of 1939, ch. 1, § 22(a), 53 Stat. 9 (now I.R.C. § 61); Treas. Reg. 103, § 19.22(a)-19 (1939).

135. Int. Rev. Code of 1939, ch. 1, §§ 115(c), 112(a), 53 Stat. 46-47, 37 (now I.R.C. $\S \S 331$, 1001(c)).

136. Treas. Reg. 62, art. 548 (1921), superseded, Treas. Reg. 103, § 19.22(a)-21 (1939).

137. Int. Rev. Code of 1939, ch. 1, $\S \S 115$ (c), 112(a), 53 Stat. 46-47, 37 (now I.R.C. $\S \S 331$, 1001(c)).

138. See id. $\S 113(\mathrm{a})(18), 53$ Stat. 44. (This rule is now codified in I.R.C. $\$ 334(\mathrm{a})$.)

139. See id. § 111(a), 53 Stat. 37 (now I.R.C. $\$ 1001(\mathrm{a})$ ). 
where shareholders were numerous or the assets indivisible. ${ }^{140}$ Moreover, the difficulties of avoiding taxation at the corporate level by distributing assets in kind were compounded by a landmark Supreme Court case, Commissioner v. Court Holding Co. ${ }^{141}$ which upheld the imposition of a corporate tax where shareholders who sold corporate assets were found to have acted inerely as a "conduit" for what was im essence a sale by the corporation.

Court Holding involved a closely held corporation whose sole asset was an apartment building. The corporation negotiated the sale of the building, and the buyer inade a partial payment of $\$ 1000$. Before the sales agreement was put in writing, however, the corporation learned that the sale would result in a large corporate gam. The next day it liquidated and distributed the building to its shareholders, who then conveyed the building to the purchaser under substantially the saine terms as had originally been agreed on and applied the $\$ 1000$ previously paid to the corporation against the purchase price. The Supreme Court upheld the Tax Court's determination ${ }^{142}$ that the sale and resulting gain were attributable to the corporation rather than to the shareholders. In other words, although the sale was technically inade by the shareholders, the Court treated the transaction as if the corporation had inade the sale prior to liquidating. ${ }^{143}$

A subsequent Supreme Court case, United States v. Cumberland Public Service Co., ${ }^{144}$ indicated that, notwithstanding Court Holding, the corporate tax could still be avoided by hquidating in kind if the proper formalities were observed. In Cumberland a closely held corporation that generated and distributed electric power was unable to compete with a local cooperative which distributed Tennessee Valley Authority power in the same area. The shareholders of the corporation offered to sell all of their stock to the cooperative, but the cooperative refused and countered with an offer to buy the corporation's transmission and distribution equipinent. The corporation rejected the offer because of the large corporate tax that would have been imposed on gain from the sale. The shareholders and the buyer then agreed that the former would acquire the transmission and distribution equipinent and

140. See, eg., Emery, Liquidating Distributions by Corporations Preceding Sale of Assets, 27 TAXES 1057, 1060-61 (1949).

141. 324 U.S. 331 (1945).

142. 2 T.C. 531 (1943), rev'd, 143 F.2d 823 (5th Cir. 1944), rev'd, 324 U.S. 331 (1945).

143. After Court Holding, a body of ritual developed to ensure that the corporation would not be deemed to have been involved in the sale. See, e.g., Bcck, Newer Methods Designed to Avoid the Court Holding Company Problem. Does a Case Like Westover v. Smith Eliminate the Court Holding Company Problem?, N.Y.U. 8Th ANN. Inst. ON Fed. TAX. 955 (1950).

144. 338 U.S. 451 (1950). 
sell it to the cooperative themselves. ${ }^{145}$ The corporation transferred this equipment to the shareholders in partial hquidation, sold the remaining assets, and then dissolved. The shareholders subsequently sold the equipment to the cooperative. The Supreme Court upheld the Court of Claims' determination ${ }^{146}$ that no corporate tax was due on the sale of the equipment to the cooperative because the corporation itself did not at any time plan to make the sale.

Justice Black, who wrote for a unanimous Court in both cases, recognized in Cumberland that the distmction between a sale by a corporation and a sale by the shareholders is "particularly shadowy and artificial" when shareholder-officers of a closely held corporation have negotiated the sale. ${ }^{147}$ Nevertheless, he concluded that the distinction was mandated by the Code that was then in effect. ${ }^{148}$

\section{B. The Congressional Response}

In 1954 Congress responded to this emphasis on formalities by enacting section 337 , which provides, with stated exceptions, ${ }^{149}$ for nonrecognition of gain or loss on a sale or exchange of property by a corporation that adopts a plan of complete hiquidation before the sale or exchange and distributes all of its assets in liquidation within the twelve-month period following the adoption of the plan. Application of section 337 results in permanent nonrecogmition of gam or loss realized on the sale or exchange, which is comparable to the treatment of distributions in kind under section 336. ${ }^{150}$

In enacting section 337 Congress clearly intended to eliminate the Court Holding-Cumberland distmction between shareholders actimg on their own behalf or on behalf of the corporation in selling corporate assets. The provision is not restricted to liquidations of closely held corporations in which such a distinction might be made, however, and the

145. Cumberland Pub. Serv. Co. v. United States, 83 F. Supp. 843, 853 (Ct. Cl. 1949), aff d, 338 U.S. 451 (1950).

146. Id. at 843 .

147. 338 U.S. at 454-55.

148. "Congress having determined that different tax consequences shall flow from different methods by which the shareholders of a closely held corporation may dispose of corporate property, we accept its mandate." Id. at 456.

149. See notes 114-16 supra and accompanying text (describing the exceptions contained in § $337(c))$. Nonrecognition under $\S 337$ is also inapplicable to sales of a corporation's inventory unless sold in bulk and to most sales of installment obligations. I.R.C. $\$ 337$ (b).

150. Section 336 is broader in scope than is $\S 337$, however, for while $\S 336$ applies to partial as well as complete hquidations, $\S 337$ applies only to complete hquidations. Thus the pre-1954 emphasis on formahties still exists with respect to partial hquidations. The House version of $\S$ 337 would have applied to both partial and complete hiquidations, see note 102 supra, but the Senate version which was enacted dropped the partial liquidation provision without explanation, see note 106 supra. For an argument that $\S 337$ should not have been limited in this way, see Gelberg, The Court Holding Cumberland Situation: Liquidation as an Incident to Sale of Assets, N.Y.U. 13Th ANN. INST. ON FED. TAX. 605, 614-15 (1955). 
legislative history suggests that Congress also intended to eliminate the tax distinction between (1) a corporate liquidation in kind followed by shareholder sales of the assets and (2) a corporate sale of the assets followed by a liquidating distribution of the sales proceeds to the shareholders. ${ }^{151}$ In recognition of this latter objective, the Tax Court, ${ }^{152}$ the Internal Revenue Service, ${ }^{153}$ and various commentators ${ }^{154}$ have stated

\footnotetext{
151. The Senate Finance Committee report stated:

Section 337 . . concerns the problems raised by the decisions in Commissioner v. Court Holding Company. . . and U.S. v. Cumberland Public Service Co. . . . . These decisions involve the question of whether the corporation or the shareholder effected a sale of property in connection with the hiquidation of the corporation. Under the decision in Cumberland Public Service Co., supra, it is indicated that in the case of a distribution of property in liquidation of a corporation followed by its sale made in fact by its shareholders, a single tax is imposed at the shareholder level. Where the shareholders in fact did not effect the sale, tax is imposed both at the corporate and at the shareholder level. Accordingly, under present law the tax consequences arising from sales made in the course of liquidations may depeud primarily upon the formal manner in which the transactions are arranged. Your committee intends in section 337 to provide a definitive rule which will eliminate the present uncertainties.
}

S. Rep. No. 1622, 83d Cong., 2d Sess. 258, reprinted in [1954] U.S. Code Cong. \& AD. News $4621,4896$.

A number of cases have cited this passage for the proposition that $\$ 337$ was enaeted to achieve tax parity between sales followed by liquidations and liquidations in kind. See, e.g., Midland-Ross Corp. v. United States, 485 F.2d 110, 114-15 (6th Cir. 1973); Commissioner v. Kuckeuberg, 309 F.2d 202, 205-06 (9th Cir. 1962), cert. denied, 373 U.S. 909 (1963); Estate of David B. Munter, 63 T.C. 663,672 (1975).

152. In holding that $\S 337$ applies to the assignment of executory contracts, the Tax Court stated:

Since the main objective of section 337 was to provide identical tax consequences whether a corporation sells its assets and then distributes the proceeds to its shareholders in complete liquidation or distributes the assets in kind to its shareholders, there arises, at least in most circumstances, a need for parity between sections 336 and 337.

John T. Stewart III Trust, 63 T.C. 682, 693 (1975), acq., 1977-1 C.B. 1 (emphasis added) (footnote quoting § 336 omitted). See also Estate of David B. Munter, 63 T.C. 663, 676-77 (1975) (since the court had not ruled on whether the tax benefit rule applied in a $\$ 336$ hiquidation, it was free to make an independent ruling on the applicability of the rule in a $\$ 337$ situation; the court held that income was realized under the tax benefit rule on a $\S 337$ sale of previously expensed property).

153. The Service has stated that "[t]he purpose of enacting section 337 was to make tax considerations a neutral factor in the determination of whether a liquidating corporation would itself sell its assets and distribute the proceeds, or, alternatively, distribute the assets to its shareholders for sale at that level." Rev. Rul. 74-396, 1974-2 C.B. 106, 107. It has issued rulings consistent with this objective. See Rev. Rul. 77-190, 1977-1 C.B. 88, 89 (\$ 337 applied to the sale of rights to service inortgage contracts, thus inaintaining parity with \& 336). See also Rev. Rul. 74-396, 19742 C.B. 106 (tax benefit recapture principles of $\$ 337$ cases applied to a $\$ 336$ liquidation under the parity rationale).

154. See, e.g., BITTKER \& EUSTICE, supra note 6:

The function of \$337- to eliminate the distimction between Court Holding Co. liquidations and Cumberland Public Service Co. liquidations-strongly suggests that $\$ 337$ should be interpreted, whenever possible, in such a way as to mimimize the disparities between ... [corporate sales under $\$ 337$ and liquidations in kind under $\$ 336$ ]. . . . In keeping with this approach, the cases and rulings exhibit a tendency to limit $\$ 337$ so as to achieve a parity between sales of assets by the corporation and distributions in kind.

...

. . . On balance, the "parity" treatunent of sales under $\$ 337$ and distributions in kind under $\$ 336 \ldots$. . has inuch to commend it as a solution to the interpretive probleins ... 
that in a novel context section 337 should generally be interpreted and applied so that the income tax consequences at the corporate level are identical whether the corporation sells the assets under section 337 or distributes the assets in kind to the shareholders under section 336 for sale by them.

\section{The Applicability of Section 337 to the Transferor Corporation in a "C" Reorganization}

In a " $\mathrm{C}$ " reorganization the transferor corporation might sell part of its assets to third parties prior to liquidating to discharge liabilities it retained or for other reasons. ${ }^{155}$ Alternatively, it might distribute all of its assets and any retained liabilities to its shareholders, ${ }^{156}$ who might later sell part of the assets received to discharge the liabilities assumed or for other reasons. Section 337 should apply to the sales to third parties under the former alternative if this would further the congressional objective of eliminating tax distinctions between these two alternative ways of structuring a liquidation coupled with a sale of corporate assets.

A transferor corporation that liquidates pursuant to a " $\mathrm{C}$ " reorganization does not recognize gain or loss on the distribution of property to its sliareholders. ${ }^{157}$ If it retains liabilities in the reorganization and distributes these to its sliareholders in liquidation, the transaction is considered for tax purposes to be an additional investment by the shareholders in their stock in the acquiring corporation, and thus the shareholders' assumption of the corporate liabilities does not result in gain to the transferor corporation. ${ }^{158}$ Since the transferor corporation's unrealized gain or loss on its assets is permanently eliminated if the assets are distributed in kind and the shareholders make the sale, the application of section 337 to sales by the corporation is consistent with the objective of neutralizing the tax consequences of these alternative ways of accoinplishing a liquidatimg sale. ${ }^{159}$

Id. at 11-69, 11-72. See also Bonovitz, Problems in Achieving Parity in Tax Treatment Under Sections 337 and 334(b)(2), N.Y.U. 34TH ANN. INST. ON FED. TAx. 57 (1976); Fleming, Judicial Error Under Scction 337 Resurrects Cumberland-Court Holding Uncertainties, 2 J. CoRP. TAX. 5 (1975); Galant, The Enigmatic Section 337: A Current Sounding, N.Y.U. 34TH ANN. INST. ON FED. TAx. 493, 496-99 (1976); Morrison, Assignment of Income and Tax Benefit Principles in Corporate Liquidations, 54 TAXES 902 (1976).

155. See notes 14-15 supra and accompanying text.

156. See, e.g., Rev. Rul. 70-271, 1970-1 C.B. 166 (situation 3); Rev. Rul. 67-411, 1967-2 C.B. 124.

157. The applicable nonrecognition provision is generally assumed to be $\S 336$. See note 90 supra.

158. Rev. Rul. 70-271, 1970-1 C.B. 166 (situation 3).

159. That the transferor corporation sells stock that it received in the reorganization rather than assets that it owned prior to the reorganization exchange should not preclude the application of $\S 337$. In Frank W. Verito, 43 T.C. 429 (1965), the Tax Court held that $\S 337$ applied to the 
Irrespective of whether section 337 applies, the timing of the recognition of gain or loss at the shareholder level on a liquidating distribution pursuant to a reorganization may differ depending on whether the corporation sells the assets or distributes thein in kind for sale by the shareholders. This results from the fact that gain that the shareholders would have to recognize if they sell corporate assets following a hquidation in kind can be deferred in the context of a reorganization if the corporation sells the assets and does not distribute the proceeds as such to the shareliolders. ${ }^{160}$ The issue thus arises whether section 337 should apply in such situations despite the absence of comparable shareholder

sale of stock purchased with the proceeds of the sale of operating assets to which $\$ 337$ applied. The court stated:

We feel that as long as the sale is not inconsistent nor incompatible with the pending liquidation, that is, as long as the corporation is in fact in the process of complete liquidation, and the sale does not violate any other subsection of section 337 , it is covercd by section 337 regardless of the fact that it takes place after the permanent operating assets have been sold.

Id. at 440 .

160. Such situations fall into three categories.

First, if the transferor corporation sells stock received in the reorganization and uses all of the proceeds to discharge retained liabilities, as was the case in $F E C$, the shareholders do not recognize their gain or loss on the liquidating distribution under $\$ 354$. The shareholders likewise would not lave recognized gain or loss under $\S 354$ had the stock and liabilities been distributed in kind, but the liabilities assuned would liave increased the basis of the stock received pro rata. See Rev. Rul. 70-271, 1970-1 C.B. 166 (situation 3); Rev. Rul. 67-411, 1967-2 C.B. 124. Thus the shareholders would lave recognized gain or loss lad they sold part of the stock received to discharge the liabilities assumed. (This timing difference may be offset in whole or in part if there are excess proceeds after the corporation discharges the liabilities, as was the case in General Housewares. See text accoinpanying note 37 supra. In this case, the shareholders must recognize their gain on the hiquidating distribution to the extent of the cash distributed under $\S 356$, whereas had the corporation distributed the stock and liabilities in kind and the shareloolders sold sufficient stock to raise the same aunount of excess cash, only the difference between the proceeds and their basis in the stock sold would have been recognizable.)

Second, the basis rules also create a timing difference at the shareholder level if the transferor corporation sells retained assets and uses the proceeds to discharge its liabilities. In this case, the sliareholders do not recognize their gain or loss on the liquidating distribution, but they would lave been required to recognize their gain to the extent of the fair inarket value of the assets distributed had the assets and liabilities been distributed in kind. (The liabilities assumed would not have been netted against the fair narket value of the assets distributed for purposes of deternining the sharelıolders' recognizable gain under $\$ 356$ but rather would have served to increase the basis in their stock in the acquiring corporation. See Rev. Rul. 70-271, 1970-1 C.B. 166 (situation 3).) The timing difference in this situation is generally greater than that in the $F E C$ situation described in the preceding paragraph, since there the gain recognized if the shareholders made the sale following a liquidation in kind was net of the shareliolders' basis in the stock sold.

Third, there is a timing difference in the tax consequences to the shareholders between a liquidation following a corporate sale and a liquidation in kind if the transferor corporation sells retained assets to third parties and either (1) transfers the proceeds to the acquiring corporation in the reorganization in exchange for additional stock in the acquiring corporation or its parent or (2) uses the proceeds to buy stock in the acquiring corporation or its parent on the open market. In either case, the slareholders do not recognize their gain on the liquidating distribution under $\S 354$, but they would have been required to recognize gain under $\S 356$ (or $\S 331$, if the assets sold represented a substantial proportion of the transferor corporation's assets, see note 6 supra and accompanying text) on an in-kind distribution of the assets sold. 
level tax consequences between these two alternative scenarios. ${ }^{161}$

The overriding purpose of Congress in enacting section 337 was to neutralize the tax treatment at the corporate level of corporate sales followed by liquidations and hquidations in kind followed by sharelolder sales. Applying section 337 to sales to third parties by a transferor corporation in a " $\mathrm{C}$ " reorganization is consistent with this objective. The fact that under certain circumstances ${ }^{162}$ the shareliolders' gain on a liquidating distribution pursuant to a reorganization may be deferred if the corporation sells its assets rather than distributes them in kind for sale by the shareholders cannot justify administrative or judicial amendment of section $337 .{ }^{163}$ A contrary conclusion "would cause the question of taxation to once again depend upon who made the sale" and therefore "would be a direct violation of the section."164

\section{CONCLUSION}

Under the literal language of the statute, section 337 is applicable to a transferor corporation that sells assets to third parties and then liquidates pursuant to both a " $C$ " reorganization and a plan of complete hquidation. Thus the question presented in the FEC and General Housewares cases is whether a judicial exception should be read into section 337 to prevent its application in that context. There is no persuasive argument for such an implied exception, and in fact limiting section 337 in that way, as the Court of Claims did in $F E C$, is contrary to the legislative purpose of neutralizing the corporate level tax consequences of corporate sales followed by hquidations and hquidations in kind followed by shareholder sales. Accordingly, as the district court properly concluded in General Housewares, section 337 should apply to

The timing differences in these situations will generally be reversed when the shareholders dispose of the stock received in the reorganization in taxable transactions. See note 12 supra.

161. The government did not raise this issue in either $F E C$ or General Housewares.

162. See note 160 supra. Gain is not necessarily deferred at the shareholder level in a $\S 337$ liquidation pursuant to a reorganization coinpared with a liquidation in kind since (1) the shareloolders may realize a loss on the liquidating distribution; (2) gain is recognized under $\S 356$ if the proceeds of the corporate sale of assets are distributed to the shareholders; and (3) gain may be recognized in the year the liquidating distribution is received notwithstanding the applicability of $\S 354$ if the shareholders proinptly dispose of their stock in the acquiring corporation or its parent, as may liave been the case in FEC. See note 29 supra. But $c f$. note 53 supra and accompanying text (prompt disposition of the stock may invalidate the reorganization because of the continuityof-interest requirement).

163. The most equitable rule might be to apply $\$ 337$ in the context of a reorganization but to require the shareholders to recognize their gain or loss on the liquidating distribution to the sane extent as they would have if the assets sold to third parties had instead been distributed in kind and sold by the shareholders. There is no basis in the existing law for sucl a requirement, however.

164. Frank W. Verito, 43 T.C. 429,440 (1965). 
[Vol. 66:623

sales to third parties by a transferor corporation in a " $\mathrm{C}$ " reorganization.

Marianne Parker Austin*

* B.A. 1969, Radcliffe College; M.B.A. 1973, Stanford Graduate School of Business; C.P.A. 1976, California State Board of Accountancy; second-year student, Boalt Hall School of Law. 